MOYA, Clara. "Los delitos de trata de seres humanos en España y Chile. Bien jurídico protegido y relaciones concursales".

Polít. crim. Vol. 11, № 22 (Diciembre 2016), Art. 6, pp. 521-547.

[http://www.politicacriminal.cl/Vol_11/n_22/Vol11N22A6.pdf]

\title{
Los delitos de trata de seres humanos en España y Chile. Bien jurídico protegido y relaciones concursales
}

\section{The crimes of trafficking in human beings in Spain and Chile. Legally protected interest and conflict of laws}

\author{
Clara Moya Guillem* \\ Profesora Ayudante de Derecho penal \\ Universidad de Alicante (España) \\ clara.mg@ua.es
}

\section{Resumen}

El bien jurídico protegido en los delitos de trata de seres humanos previstos en España y Chile ha sido objeto de interesantes debates doctrinales. En el presente trabajo se examinan de manera conjunta las cuatro tesis defendidas mayoritariamente: la dignidad de la víctima, su integridad moral, su libertad y la pluriofensividad del delito, puesto que la gran similitud entre las figuras delictivas de ambos países permite llevar a cabo este análisis global; y, a continuación, se dan las razones para apoyar una de ellas. Planteada la determinación del bien jurídico protegido que se considera más adecuada, por un lado, se delimita la relación concursal existente entre los delitos de trata de seres humanos y aquellos que sancionan la explotación perseguida (delitos contra la libertad sexual, delitos contra los derechos de los trabajadores y delitos de tráfico de órganos humanos); y, por otro lado, se llega a la conclusión de que los delitos de trata de seres humanos examinados no tienen el alcance que se pretendía desde el Derecho internacional.

Palabras clave: Bien jurídico protegido, trata de seres humanos, explotación, relaciones concursales.

\begin{abstract}
The legally protected interest in crimes of trafficking in human beings as defined in Spain and Chile has been the subject of interesting doctrinal debates. This paper examines the four main theses argued: the victim's dignity, the victim's moral integrity, the victim's freedom and the multi-offence nature of the crime; since the strong similarity between the definitions of offences in both countries permits a global analysis, and following this analysis, the grounds are given for supporting one of these theses. Having determined the legally protected interest considered most appropriate, on one side, the conflict of laws

\footnotetext{
* La investigación cuyos resultados se exponen en el presente trabajo se desarrolló durante una estancia de investigación realizada en el Centro de Estudios de Derecho Penal de la Universidad de Talca financiada por la Beca Iberoamericana para Jóvenes Investigadores (España 2015) del Banco Santander (Santander Universidad). Doy las gracias a los profesores de dicho centro, especialmente al profesor Carnevali, por el inmejorable trato que recibí.
} 
MOYA, Clara. "Los delitos de trata de seres humanos en España y Chile. Bien jurídico protegido y relaciones concursales".

between crimes of human trafficking and crimes of exploitation (crimes against sexual freedom, crimes against workers' rights and crimes of trafficking in human organs) is defined; and, on the other hand, it is concluded that the crimes of trafficking in human beings examined do not have the scope intended in international law.

Key words: Legally protected interest, trafficking in human beings, exploitation, conflict of laws.

\section{Introducción.}

La trata de seres humanos constituye una violación flagrante de los derechos humanos, que genera, aproximadamente, 150.200 millones de dólares en beneficios ilegales cada año ${ }^{1}$ y deja tras de sí cientos de miles de víctimas ${ }^{2}$.

Teniendo en cuenta la envergadura del fenómeno, en los últimos años se han aprobado numerosos instrumentos normativos internacionales con la finalidad de combatirlo ${ }^{3}$. De ellos, tanto España como Chile han ratificado el Protocolo para prevenir, reprimir y sancionar la trata de personas, especialmente mujeres y niños (en adelante, Protocolo de Palermo) en los años 2002 y 2004, respectivamente.

Este texto, elaborado en el seno de las Naciones Unidas, fue el primero en abordar el problema de la trata de seres humanos desde un triple enfoque: la prevención, la persecución criminal y la protección de las víctimas ${ }^{4}$, invitando a los Estados, para la

${ }^{1}$ Así lo testifica el Informe de la Relatora Especial de Naciones Unidas sobre la Trata de personas (A/HRC/29/38), de 31 de marzo de 2015. En este documento se especifica que la trata de seres humanos representa una violación grave de los derechos humanos, especialmente, del derecho a la libertad y a no ser sometido a esclavitud ni a servidumbre involuntaria, el derecho a no ser objeto de trato cruel o inhumano, el derecho a no sufrir violencia y el derecho a la salud.

${ }^{2}$ Como se indica en el Informe Mundial sobre la Trata de Seres Humanos de la UNODC, de 2014, la trata de personas afecta a prácticamente todos los países de todas las regiones del mundo. En particular, entre 2010 y 2012 se identificaron víctimas de 152 nacionalidades diferentes en 124 países de todo el mundo. En América Latina y el Caribe se estima que son víctimas de trata de seres humanos entre 600.000 y 800.000 personas. Sobre este y otros datos, véase el Informe anual 2011 sobre la situación de los Derechos Humanos en Chile del Instituto Nacional de Derechos Humanos. Por su parte, en Europa, el Informe de 2014 de la Comisión Europea Mid-term report on the implementation of the EU strategy towards the erradication of trafficking in human beings [COM(2014)635 final] revela que durante los años 2010, 2011 y 2012 entre los 28 Estados parte tuvieron constancia de más de 30.000 víctimas de trata de seres humanos.

${ }^{3}$ Además del Protocolo de Palermo, al que me refiero en el texto, resultan especialmente relevantes, por lo que a España se refiere, la Directiva 2011/36/UE, del Parlamento Europeo y del Consejo, de 5 de abril de 2011, relativa a la prevención y lucha contra la trata de seres humanos y a la protección de las víctimas; y el Convenio sobre la lucha contra la Trata de seres humanos del año 2005 (conocido como el Convenio de Varsovia); y por lo que respecta a Chile, destaca, sobre todo, el Plan de Acción del MERCOSUR para la Lucha contra la Trata de personas de 2013.

${ }^{4}$ Es por ello por lo que "se conoce a esta aproximación estratégica a la trata como política de 3P, porque cubre tanto el flanco de la prevención de estas conductas, cuanto el de la protección de las víctimas, además de la persecución criminal de las mismas" (VILLACAMPA ESTIARTE, Carolina, "Víctimas de la trata de seres humanos: su tutela a la luz de las últimas reformas penales sustantivas y procesales proyectadas", Indret $\mathrm{n}^{\circ} 2$ (2014), p. 4). No obstante, reformulando la llamada "Estrategia 3P", hay quien llega a proponer un "Enfoque 5P", incorporando a las tres estrategias apuntadas, la de prestación de servicios a las víctimas y, sobre todo, la apertura de cauces a la participación de la sociedad civil (muy en particular, las ONGs) y la 


\section{Polít. crim. Vol. 11, № 22 (Diciembre 2016), Art. 6, pp. 521-547. \\ [http://www.politicacriminal.cl/Vol_11/n_22/Vol11N22A6.pdf]}

consecución del segundo de estos propósitos, a que tipificasen expresamente el delito de trata de seres humanos, que se definía del siguiente modo:

"La captación, el transporte, el traslado, la acogida o la recepción de personas, recurriendo a la amenaza o al uso de la fuerza u otras formas de coacción, al rapto, al fraude, al engaño, al abuso de poder o de una situación de vulnerabilidad o a la concesión o recepción de pagos o beneficios para obtener el consentimiento de una persona que tenga autoridad sobre otra, con fines de explotación. Esa explotación incluirá, como mínimo, la explotación de la prostitución ajena u otras formas de explotación sexual, los trabajos o servicios forzados, la esclavitud o las prácticas análogas a la esclavitud, la servidumbre o la extracción de órganos" (art. 3).

Como puede observarse, el concepto de trata de seres humanos establecido en el Protocolo de Palermo, que es el que se reitera en las sucesivas normas internacionales sobre la materia, se caracteriza por la concurrencia de tres elementos: la conducta (captar, transportar, trasladar, acoger o recibir al sujeto pasivo), el medio de determinación de la voluntad de la víctima (la amenaza, el uso de la fuerza u otras formas de coacción, el rapto, el fraude, el engaño, el abuso de poder o de una situación de vulnerabilidad o la concesión o recepción de pagos o beneficios para obtener el consentimiento de una persona que tenga autoridad sobre otra) y la finalidad de explotación. Y, del mismo modo, los Estados que han ratificado alguno de los textos legales internacionales contra la trata de seres humanos requieren, en sus respectivas legislaciones penales, para que se estime consumado el delito de trata de seres humanos, que se realice alguna de esas conductas típicas empleando alguno de esos medios de determinación de la voluntad de la víctima con la finalidad de explotarla.

Entre los Estados que han ratificado el Protocolo de Palermo y que, por ende, han tipificado la trata de seres humanos en estos términos se encuentran España y Chile.

España incorporó el delito de trata de seres humanos al Código penal mediante la Ley Orgánica 5/2010 (art. 177 bis C.p.). Este tipo, tras la reforma operada por la Ley Orgánica $1 / 2015$, castiga con la pena de prisión de cinco a ocho años al que:

"empleando violencia, intimidación o engaño, o abusando de una situación de superioridad o de necesidad o de vulnerabilidad de la víctima nacional o extranjera, o mediante la entrega o recepción de pagos o beneficios para lograr el consentimiento de la persona que poseyera el control sobre la víctima, la captare, transportare, trasladare, acogiere, o recibiere, incluido el intercambio o transferencia de control sobre esas personas, con cualquiera de las finalidades siguientes:

a) La imposición de trabajo o de servicios forzados, la esclavitud o prácticas similares a la esclavitud, a la servidumbre o a la mendicidad.

b) La explotación sexual, incluyendo la pornografía.

c) La explotación para realizar actividades delictivas.

coordinación interinstitucional en cualquier plan o actividad dirigidos contra la trata de personas. Sobre esta propuesta, véase DE LA CUESTA ARZAMENDI, José Luis, "Tráfico y trata de seres humanos: regulación internacional y europea", en: RICHARD GONZÁLEZ, Manuel, RIAÑO BRUN, Iñaki y POELEMANS, Maitena (Coords.), Estudios sobre la lucha contra la trata de seres humanos, Pamplona: Aranzadi, 2013, p. 67. 
MOYA, Clara. "Los delitos de trata de seres humanos en España y Chile. Bien jurídico protegido y relaciones concursales".

d) La extracción de sus órganos corporales.

e) La celebración de matrimonios forzados".

Por su parte, Chile creó el delito de trata de seres humanos mediante la Ley núm. 20.507 de 2011 (art. 411 quater C.p.). Esta figura delictiva sanciona con la pena de reclusión mayor en sus grados mínimo a medio al que

"mediante violencia, intimidación, coacción, engaño, abuso de poder, aprovechamiento de una situación de vulnerabilidad o de dependencia de la víctima, o la concesión o recepción de pagos u otros beneficios para obtener el consentimiento de una persona que tenga autoridad sobre otra capte, traslade, acoja o reciba personas para que sean objeto de alguna forma de explotación sexual, incluyendo la pornografía, trabajos o servicios forzados, servidumbre o esclavitud o prácticas análogas a esta, o extracción de órganos".

Así pues, la legislación penal española y chilena han regulado la trata de seres humanos de un modo prácticamente idéntico. Las tres únicas diferencias entre los mencionados delitos son las siguientes: en primer lugar, que en la legislación española aparece como conducta típica del delito de trata de seres humanos "el intercambio o transferencia de control sobre esas personas", que no se sanciona expresamente en el tipo penal chileno; en segundo lugar, que en el delito español se han incluido como finalidades de explotación: la celebración de matrimonios forzados y la explotación para realizar actividades delictivas, que en la figura delictiva chilena no aparecen ${ }^{6}$; y, en tercer lugar, que en el artículo 411 quater del Código penal chileno se ha previsto como medio de determinación de voluntad de la víctima "la coacción”, que en el tipo penal español de trata de seres humanos no se prevé.

Sin embargo, estas tres diferencias en absoluto conllevan que ambos delitos adquieran un alcance distinto ni resultan condicionantes para la determinación del bien jurídico protegido. Por lo que se refiere a la primera discrepancia señalada, puede considerarse que "el intercambio o transferencia de control sobre esas personas" también está implícitamente sancionado en el artículo 411 quater del Código penal chileno porque en el delito español se ha regulado como una modalidad de "recepción" y no como una conducta independiente; en relación con la segunda diferencia, las dos finalidades de explotación que se han añadido al artículo 177 bis del Código penal español, según estima la doctrina, pueden subsumirse en los servicios forzados ${ }^{7}$, por lo que también podría interpretarse que se prevén en la

\footnotetext{
${ }^{5}$ Según el artículo 56 del Código penal chileno, la pena de reclusión mayor en sus grados mínimo a medio equivale a una pena de prisión de 5 a 15 años.

${ }^{6}$ En España hasta la aprobación de la Ley Orgánica 1/2015, eran tres los fines previstos en el delito de trata de seres humanos: la explotación laboral, la explotación sexual y la extracción de órganos (que son los previstos, actualmente, en el delito chileno). Sin embargo, a partir de la modificación que ha supuesto esta norma en el artículo 177 bis del Código penal también existe delito de trata de seres humanos cuando las conductas previstas en este precepto vayan dirigidas a la celebración de matrimonios forzados o a la explotación para realizar actividades delictivas. Asimismo, la reforma operada en el delito del artículo 177 bis del Código penal español mediante la Ley Orgánica 1/2015 ha incluido como una forma de "recepción", "el intercambio o transferencia de control sobre esas personas", que es, como se ha visto, otro de los elementos discrepantes entre los delitos de trata de seres humanos en estudio.

${ }^{7}$ Realizan esta interpretación, entre otros, IGLESIAS SKULJ, Agustina, "De la trata de seres humanos: artículo 177 bis C.p.”, en: GONZÁLEZ CUSSAC, José Luis (Dir.), Comentarios a la reforma del Código
} 


\section{Polít. crim. Vol. 11, No 22 (Diciembre 2016), Art. 6, pp. 521-547. \\ [http://www.politicacriminal.cl/Vol_11/n_22/Vol11N22A6.pdf]}

legislación penal chilena; y, sobre la tercera divergencia, aunque la coacción no se haya establecido expresamente en el delito español como una forma de determinación de la voluntad de la víctima, resulta indiscutiblemente abarcada por la violencia, que sí se contempla.

Considerando, entonces, la gran similitud entre ambas figuras delictivas, en el presente trabajo me voy a referir a "los delitos de trata de seres humanos" para examinar indistintamente el tipo penal español y el chileno, porque entiendo que los argumentos que voy a sostener son perfectamente aceptables en ambos casos.

En particular, en la primera parte del trabajo abordaré el bien jurídico protegido en estas figuras delictivas y en la segunda concretaré la relación concursal existente entre estos y los delitos que materializan la explotación que con la trata de seres humanos se persigue. Finalmente, dedicaré las conclusiones a explicar por qué, a pesar de las declaraciones de los legisladores penales nacionales ${ }^{8}$, los delitos de trata de seres humanos previstos en España y Chile no son una mera transposición de la normativa internacional y señalaré las consecuencias que derivan de esta distinta configuración.

\section{El bien jurídico protegido en los delitos de trata de seres humanos.}

Como ha considerado Soto Donoso, "en el plano de la trata de personas el problema del bien jurídico se torna complejo, no por su debilidad o carencia, sino que al contrario, por la

penal de 2015, Valencia: Tirant lo Blanch, 2015, pp. 593-601, p. 599; y VILLACAMPA ESTIARTE, Carolina, "La trata de seres humanos tras la reforma del Código penal de 2015", Diario La Ley, n 8554 (2015).

${ }^{8}$ El Preámbulo de la Ley Orgánica 1/2015, que reforma el delito español de trata de seres humanos, justifica tal modificación del siguiente modo: "la reforma operada en el Código Penal por la Ley Orgánica 5/2010, de 22 de junio, introdujo el delito de trata de seres humanos en el actual artículo 177 bis. Este delito se tipificó con anterioridad a la Directiva 2011/36/UE, de 5 abril de 2011, relativa a la prevención y lucha contra la trata de seres humanos y a la protección de las víctimas y por la que se sustituye la Decisión marco 2002/629/JAI del Consejo. Aunque la reforma del año 2010 tuvo en cuenta el proyecto que finalmente se materializó en la citada Directiva, existen varias cuestiones que no fueron reflejadas en la redacción actual y que es preciso incluir para una completa transposición de la normativa europea". Y, en cuanto al delito chileno, el Proyecto de Ley que tipifica el delito de tráfico de niños y personas adultas y establece normas para su prevención y más efectiva persecución criminal (Boletín 3778-18) puso de manifiesto la necesidad de incorporar a la legislación chilena "la figura general del tráfico de personas en los términos definidos por el artículo 3 del Protocolo de Palermo". Concretamente, se expuso lo siguiente: "Chile no puede seguir quedándose atrás en la materia. Pese a las declaraciones de algunos representantes del Ejecutivo en el Congreso Nacional durante el análisis de la Convención de Palermo y de su Protocolo complementario referido a tráfico de personas, en nuestro país, no existen todos los medios institucionales, sean estos normativos como de políticas públicas preventivas que permitan sostener que Chile cumple con los estándares internacionales en la materia. Por lo anterior es que proponemos a esta Honorable Cámara este Proyecto de Ley que se divide en cuatro títulos. El primero que hemos denominado "De los Delitos Contra la Libertad e Integridad Física de las Personas Vinculados al Tráfico de Personas", en el cual, siguiendo los mandatos internacionales hemos tipificado el delito de promoción del tráfico de personas, el delito de trata o tráfico de personas, la venta de personas y la participación en asociaciones ilícitas para el tráfico de personas". Del mismo modo, indicaron que esta incriminación se originaba en el Derecho internacional y, específicamente, en el Protocolo de Palermo tanto el Informe de la Comisión de familia referido al proyecto de ley, como el Informe de la Comisión de derechos humanos, nacionalidad y ciudadanía, como el Segundo Informe de la Comisión de Constitución, legislación, justicia y reglamento. 
MOYA, Clara. "Los delitos de trata de seres humanos en España y Chile. Bien jurídico protegido y relaciones concursales".

frondosidad de su contenido, pues la comunidad internacional ha entendido que son variados los valores comprometidos en la realización de las conductas constitutivas de la trata de personas" 9 .

Al respecto, en el Preámbulo de la Ley Orgánica 5/2010, por la que se incrimina la trata de seres humanos en España, se establece que "el artículo 177 bis tipifica un delito en el que prevalece la protección de la dignidad y la libertad de los sujetos pasivos que la sufren". Sin embargo, entre la doctrina española se discute si el concreto interés tutelado en esta figura delictiva se identifica con la dignidad, con la integridad moral, con la libertad o si este no sería más bien un delito pluriofensivo.

Y, en Chile, es la Ley núm. 20.507 de 2011 la que incorporó el artículo 411 quater al Código penal, sancionando, de este modo, la trata de seres humanos en el título "De los delitos de tráfico ilícito de migrantes y trata de personas". Sobre este ilícito la doctrina chilena coincide en afirmar que se trata de un delito pluriofensivo. No obstante, se debate qué bienes se tutelan conjuntamente ${ }^{10}$.

En suma, la doctrina discute cuál es el bien jurídico protegido en los delitos de trata de seres humanos, siendo cuatro las tesis que sostiene de manera mayoritaria: la dignidad, la integridad moral, la libertad y la pluriofensividad delictiva. Pues bien, seguidamente, indicaré cuáles son los argumentos a favor y en contra de cada una de estas tesis ${ }^{11}$.

\subsection{La dignidad.}

Gran parte de la doctrina considera que los delitos de trata de seres humanos protegen la dignidad del sujeto pasivo ${ }^{12}$.

\footnotetext{
9 SOTO DONOSO, Francisco, "Aspectos dogmáticos del delito de trata de personas del artículo $3^{\circ}$ del Protocolo de Palermo", Revista Jurídica del Ministerio público, no 39 (2009), pp. 170-184, p. 174. Igualmente, Gajardo Orellana y Torres Figueroa entienden que, sin duda, el bien jurídico protegido debe ser el aspecto que más dudas genera en relación con el delito de trata de personas (en "Los tipos penales de tráfico de migrantes y trata de personas en la Ley 20.507”, Revista Jurídica del Ministerio Público, n 47 (2011), pp. 231-251, p. 249).

${ }^{10}$ Carnevali sostiene que se tutelan la libertad, la seguridad personal y la salud (en: CARNEVALI, Raúl, "La trata de personas y la normativa internacional. Algunas consideraciones de su regulación en Chile", Revista de Diritto Penale Contemporaneo, $\mathrm{n}^{\circ} 4$ (2013), pp. 170-186, p. 182); y Soto Donoso establece que el delito de trata de seres humanos es pluriofensivo, porque "cautela diversos bienes jurídicos de carácter personalísimo, como la vida e integridad física y psíquica, libertad y seguridad personal, libertad sexual individual, indemnidad o intangibilidad sexual, libertad de tránsito y de residencia, libertad de trabajo, vida privada y honra" (en: SOTO DONOSO, “Aspectos dogmáticos del delito de trata de personas", cit. nota no 9, p. 174). Finalmente, en la Conferencia Regional sobre Migración de 2008, Gabriela Rodríguez Pizarro afirmó que el bien jurídico protegido varía según los casos, pero puede ser: la vida, la libertad, y la dignidad y la libertad física. Al respecto, RODRÍGUEZ PIZARRO, Gabriela, Ponencia en la mesa de trabajo "Migración, derechos humanos y ciudadanía" de la Conferencia Regional sobre Migración, disponible en http://www.crmsv.org/documentos/SEGIB/7\%20terceraParte.pdf [última consulta: 13/11/2015].

${ }^{11}$ Adviértase que el tratamiento jurídico-penal de la trata de menores no será objeto de análisis en el presente trabajo. Sobre esta problemática, véase BOLDOVA PASAMAR, Miguel Ángel, et al, "Trata de seres humanos. En especial menores", Revista de Derecho migratorio y Extranjería, no 23 (2010), pp. 51-112.

${ }^{12}$ QUERALT JIMÉNEZ, Joan Josep, Derecho penal español. Parte especial, Valencia: Tirant lo Blanch, 2015, p. 172; IGLESIAS SKULJ, "De la trata de seres humanos: artículo 177 bis C.p.”, cit. nota nº 8, p. 598;
} 


\section{Polít. crim. Vol. 11, No 22 (Diciembre 2016), Art. 6, pp. 521-547. [http://www.politicacriminal.cl/Vol_11/n_22/Vol11N22A6.pdf]}

Los autores partidarios de esta tesis sostienen que cuando se llevan a cabo las conductas de trata de seres humanos se despoja a la víctima de la capacidad de decidir sobre sus derechos más importantes con la finalidad de realizar posteriormente un negocio o satisfacer cualquier interés del sujeto activo o de un tercero ${ }^{13}$. De esta manera, estiman que se atenta contra la dignidad humana porque se le niega a la persona su condición de ser humano, al tratarle como un medio y no como un fin. En este sentido, Queralt Jiménez afirma que:

"el bien jurídico penalmente protegido aquí tiene grandes resonancias y, por una vez, son las adecuadas, la dignidad humana. Quienes se dedican a la trata de personas no conciben a sus congéneres como tales: los cosifican y, por tanto, les privan de la más leve brizna de humanidad. Esta, junto con otras lacras, como las del hambre, son incompatibles con la dignidad humana y chocan frontalmente, degradándola"14. Incluso, algunos autores, tras este razonamiento, llegan a afirmar que el fenómeno de la trata de seres humanos representa la esclavitud del siglo XXI ${ }^{15}$.

DAUNIS RODRÍGUEZ, Alberto, El delito de trata de seres humanos, Valencia: Tirant lo Blanch, 2013, pp. 73-81; VILLACAMPA ESTIARTE, Carolina, El delito de trata de seres humanos. Una incriminación dictada desde el Derecho internacional, Pamplona: Aranzadi, 2011, pp. 396-409; TERRADILLOS BASOCO, Juan María, "Trata de seres humanos”, en: ÁLVAREZ GARCÍA, Francisco Javier y GONZÁLEZ CUSSAC, José Luis (Dirs.), Comentarios a la reforma de 2010, Valencia: Tirant lo Blanch, 2010, pp. 207217, p. 208; CUGAT MAURI, Miriam, "Trata de seres humanos: la universalización del tráfico de personas y su disociación de las conductas infractoras de la política migratoria", en: QUINTERO OLIVARES, Gonzalo (Dir.), La reforma penal de 2010: Análisis y comentarios, Pamplona: Aranzadi, 2010, pp. 157-164, p. 160; LLORIA GARCÍA, Paz, "Trata de seres humanos", en: BOIX REIG, Javier (Dir.), Derecho penal. Parte especial. Volumen I, Madrid: Iustel, 2010, pp. 293-313, p. 297; JUANES PECES, Ángel, "El delito de trata de seres humanos en el Proyecto de Reforma del Código penal de 1995", Actualidad Jurídica Aranzadi, no 803 (2010); RODRÍGUEZ FERNÁNDEZ, Ignacio, "Trata de personas", en: ORTIZ DE URBINA GIMENO, Íñigo (Coord.), Memento experto. Reforma penal, Madrid: Ediciones Francis Lefebvre, 2010, pp. 71-88, p. 73; y RODRÍGUEZ PIZARRO, Ponencia en mesa de trabajo "Migración, derechos humanos y ciudadanía", cit. nota $\mathrm{n}^{\circ} 10$.

${ }^{13}$ DAUNIS RODRÍGUEZ, El delito de trata de seres humanos, cit. nota $\mathrm{n}^{\circ}$ 12, p. 73.

${ }^{14}$ QUERALT JIMÉNEZ, Derecho penal español. Parte especial, cit. nota no 12, p. 197.

${ }^{15}$ El Estatuto de Roma contempla, entre los crímenes de lesa humanidad establecidos en su artículo 7.1, la esclavitud, y la define, a tales efectos, como "el ejercicio de los atributos del derecho de propiedad sobre una persona, o de alguno de ellos, incluido el ejercicio de esos atributos en el tráfico de personas, en particular mujeres y niños". La trata de seres humanos, en cambio, se define, generalmente, como un acto de comercio de personas que conlleva la pretensión ulterior de obtener provecho económico del mismo, siendo inherente el desplazamiento o traslado de las personas, análogamente a como se hace con las mercancías en los ámbitos comerciales. Así pues, según se estima, indistintamente de cómo este acto de comercio se lleve a cabo, existirá un denominador común que consistirá en tratar a la víctima como una cosa. Esta definición la ofrece BOLAÑOS VÁSQUEZ, Hazel Jasmin, "Regulación jurídico-penal de la trata de personas según el Protocolo de Palermo. Aplicación práctica desde la teoría del delito", Revista de Derecho Migratorio y Extranjería, ${ }^{\circ}$ 34 (2013), pp. 295-314. Pues bien, a pesar de estas definiciones, realizan esta comparación entre la trata de seres humanos y la esclavitud, entre otros, QUERALT JIMÉNEZ, Derecho penal español. Parte especial, cit. nota $\mathrm{n}^{\circ}$ 12, p. 172; RODRÍGUEZ FERNÁNDEZ, "Trata de personas", cit. nota $\mathrm{n}^{\mathrm{o}} 12$, p. 73; y GARCÍA ARÁN, Mercedes, "Esclavitud y tráfico de seres humanos", en: OCTAVIO DE TOLEDO Y UBIETO, Emilio, GURDIEL SIERRA, Manuel y CORTÉS BECHIARELLI, Emilio (Coords.), Estudios penales en recuerdo del profesor Ruiz Antón, Valencia: Tirant lo Blanch, 2004, pp. 355-378, p. 359. Algunos textos normativos internacionales, no obstante, insisten en que se distinga la esclavitud de la trata de esclavos. Así, en el Convenio de Ginebra sobre la represión de la esclavitud de 1926 se define la esclavitud como "el estado o condición de un individuo sobre el cual se ejercitan los atributos del derecho de propiedad o alguno de ellos", mientras que la trata de esclavos "comprende todo acto de captura, adquisición o cesión de un individuo para venderle o cambiarle y en general, todo acto de comercio o transporte de esclavos" (art. 1). Y 
MOYA, Clara. "Los delitos de trata de seres humanos en España y Chile. Bien jurídico protegido y relaciones concursales".

Como sostiene Villacampa Estiarte, la dignidad humana se identifica, en este ámbito, con la prohibición de instrumentalizar a la persona, pero también con el respeto a la integridad (física y moral) del ser humano, a su libertad y a la igualdad ${ }^{16}$. Es por esta razón por la que los partidarios de esta opción estiman que la determinación de uno sólo de estos intereses como el bien jurídico protegido en los delitos de trata de seres humanos resulta insuficiente, ya que tratan de tutelarse todos ellos ${ }^{17}$.

Esta postura doctrinal, sin embargo, se enfrenta a un doble obstáculo: por un lado, la aceptación de la dignidad como bien jurídico-penal; y, por otro lado, su concreto alcance.

En relación con el primero de estos obstáculos, algunos autores estiman que la dignidad humana no es un derecho en sí mismo, sino un principio o valor que se predica de todos los derechos protegidos jurídico-penalmente: vida, integridad, libertad, honor, etc. De este modo, argumentan que todos los derechos individuales serían porciones autónomas derivadas de la dignidad humana. Siendo ello así, entre otros, Gracia Martín afirma que la dignidad humana no es ningún bien jurídico-penal, sino un atributo totalizador, "una síntesis de la totalidad de dimensiones físicas y espirituales específicas de la persona humana" $"$. También, en esta dirección, Peris Riera y García González sostienen que:

"la dignidad no parece adecuado considerarla bien jurídico protegido de ningún delito porque cualquier delito que lesione un interés de la persona de alguna manera afecta también a su dignidad, y a nadie se le ocurre afirmar que es este el bien jurídico de los delitos de homicidio o lesiones. De hacerlo, entraríamos en la dinámica de configurar bienes jurídicos difusos, indeterminados, con la consecuente dificultad de concretar la virtualidad del principio de ofensividad y alcanzando así, como consecuencia de todo ello, un adelantamiento de la barrera punitiva a todas luces indeseable" ${ }^{\prime 19}$.

Y el segundo obstáculo a la configuración de la dignidad humana como el bien jurídico protegido en los delitos de trata de seres humanos reside en que se apela a ella tan

la misma distinción aparece tanto en el artículo 4 de la Declaración universal de los Derechos Humanos de 1948 como en el artículo 8 del Pacto de Derechos civiles y Políticos de Nueva York de 1966.

${ }^{16}$ Acerca del alcance de la dignidad humana en el contexto español del delito de trata de seres humanos, véase VILLACAMPA ESTIARTE, Carolina, "Título VII bis", en: QUINTERO OLIVARES, Gonzalo (Dir.), Comentarios a la Parte especial del Derecho penal, Pamplona: Aranzadi, 2011, pp. 265-303, p. 283.

${ }^{17}$ Villacampa Estiarte sostiene que "precisamente porque el proceso de trata implica un atentado a la misma línea de flotación de la personalidad humana, porque supone una vulneración de la esencia misma de la persona, la negación de su humanidad, debe reclamarse que sea la dignidad y no otro interés el que integre el bien jurídico protegido por el delito" (VILLACAMPA ESTIARTE, El delito de trata de seres humanos, cit. nota $\mathrm{n}^{\circ} 12$, p. 404).

${ }^{18}$ GRACIA MARTÍN, Luis, "El delito y la falta de malos tratos en el Código penal español de 1995", Actualidad Penal, 1996, p. 581.

${ }^{19}$ PERIS RIERA, Jaime Miguel y GARCÍA GONZÁLEZ, Javier, "El bien jurídico protegido en los delitos relativos a la manipulación genética: criterios de incriminación", en: BENÍTEZ ORTÚZAR, Ignacio Francisco, MORILLAS CUEVA, Lorenzo y PERIS RIERA, Jaime Miguel, Estudios jurídico-penales sobre genética y biomedicina, Madrid: Dykinson, 2005, p. 116. Así pues, Mapelli Caffarena rechaza la dignidad como el bien jurídico protegido en el delito español de trata de seres humanos (MAPELLI CAFFARENA, Borja, "La trata de personas", Anuario de Derecho penal y Ciencias penales, vol. LXV, 2012, pp. 25-62, p. 49) y Carnevali hace lo propio en relación con el tipo chileno (CARNEVALI, "La trata de personas y la normativa internacional.", cit. nota $\mathrm{n}^{\mathrm{o}} 10, \mathrm{p} .182$ ). 


\section{Polít. crim. Vol. 11, № 22 (Diciembre 2016), Art. 6, pp. 521-547. \\ [http://www.politicacriminal.cl/Vol_11/n_22/Vol11N22A6.pdf]}

frecuentemente y desde perspectivas tan diversas y contradictorias que su significado resulta difícil de especificar. En este sentido, Tomás-Valiente Lanuza explica cómo mientras que existe acuerdo sobre el concepto de dignidad en tanto que valor intrínseco al ser humano por el mero hecho de serlo, que le hace acreedor de consideración y respeto; coexisten muchas concepciones acerca de su contenido y de los tratos o prácticas que la vulneran. Así, en su repaso por las consecuencias normativas de la dignidad de la persona y las distintas aplicaciones jurídicas de cada una de ellas, hace referencia a las siguientes vertientes: a) la obligación de reconocimiento de un mínimo invulnerable que se impone a todos los poderes públicos a la hora de configurar el estatuto jurídico de las personas; b) la exigencia de cierta suficiencia económica en determinados ámbitos; c) la exigencia de respeto a las decisiones libremente adoptadas (la dignidad como autodeterminación); y d) la prohibición de instrumentalización de la persona ${ }^{20}$.

Por estos dos inconvenientes (no reunir los requisitos que la Dogmática exige a los bienes jurídicos para ser penalmente protegidos y no servir para legitimar una concreta intervención penal por su excesiva amplitud y vaguedad), rechazo que la dignidad humana sea el bien jurídico protegido inmediatamente en los delitos de trata de seres humanos ${ }^{21}$. En consecuencia, deben examinarse otras alternativas, a las que a continuación voy a referirme.

\subsection{La integridad moral.}

Algunos autores sostienen que el bien jurídico-penal que se tutela en los delitos de trata de seres humanos se ha de identificar con la integridad moral ${ }^{22}$. Todos ellos consideran que estas figuras delictivas pueden concebirse como modalidades específicas de ataque contra este interés, en la medida en que la instrumentalización del ser humano para la consecución de determinadas finalidades mercantilistas supone involucrarle en una situación que lo anula como persona ${ }^{23}$.

20 TOMÁS-VALIENTE LANUZA, Carmen, "La dignidad y sus consideraciones normativas en la argumentación jurídica: ¿un concepto útil?”, Revista Española de Derecho Constitucional, no 102 (2014), pp. 167-208.

${ }^{21}$ Hace también referencia a estos dos argumentos para descartar la dignidad humana como un bien jurídicopenal, DE LA CUESTA AGUADO, Paz, Delitos de tráfico ilegal de personas, objetos y mercancías, Valencia: Tirant lo Blanch, 2013, pp. 16-17.

${ }^{22}$ En esta línea, entre otros, NIETO GARCÍA, Ángel Juan, "Concurso penal de la trata de seres humanos y utilización de menores como mendigos”, Diario La Ley, no 7867 (2012); MARTOS NÚÑEZ, José Antonio, "El delito de trata de seres humanos: análisis del artículo 177 bis del Código penal", Estudios penales y criminológicos, $\mathrm{n}^{\mathrm{o}} 32$ (2012), pp. 97-130, p. 100; y BENÍTEZ ORTÚZAR, Ignacio Francisco, “Capítulo 10. Trata de seres humanos", en: MORILLAS CUEVA, Lorenzo (Coord.), Sistema de Derecho penal español. Parte especial, Madrid: Dykinson, Madrid, 2011, pp. 213-231, pp. 227 y 228. También, en este sentido, en la Sentencia de la AP de Barcelona 9/2013, de 6 de febrero, se estima que "la protección del bien jurídico en la trata de seres humanos se vincula a la afectación a la dignidad humana y por lo tanto a la integridad moral".

${ }^{23}$ Aunque en Chile también se proclama la integridad moral como un derecho fundamental, la doctrina no se ha referido a ella en relación con el delito del artículo 411 quater del Código penal, sino que ha apreciado, en este ámbito, que los bienes jurídicos protegidos son, simultáneamente, la libertad y la seguridad personal. Entre otros, han adoptado esta postura, CARNEVALI, "La trata de personas y la normativa internacional.", cit. nota $\mathrm{n}^{\circ}$ 10, p. 182; GUZMÁN DALBORA, José Luis, "La trata de seres humanos y el problema de su bien jurídico", Revista procesal penal, no 62 (2007), pp. 9-19, p. 14; y SOTO DONOSO, “Aspectos dogmáticos del delito de trata de personas", cit. nota $n^{\circ} 9$, p. 176. Este último autor, concretamente, afirma que "para 
MOYA, Clara. "Los delitos de trata de seres humanos en España y Chile. Bien jurídico protegido y relaciones concursales".

Los defensores de este bien jurídico protegido en los delitos de trata de seres humanos definen este interés, por lo que respecta a estos delitos, de una manera muy similar a como lo hacen los partidarios de la dignidad de la víctima. Esto se debe a que, como ha advertido Alonso Álamo, "la línea entre la dignidad y la integridad moral, si la hubiera, sería extremadamente fina, pues con el reconocimiento del derecho a la integridad moral se está concretando el núcleo esencial, el último reducto, de la dignidad"24. Pero, el sector doctrinal que se adhiere a la integridad moral como el bien jurídico protegido en los delitos de trata de seres humanos lo hace porque entiende que, por las razones ya expuestas, la dignidad humana no puede ser considerada un bien jurídico-penal y estima que, en su vertiente de prohibición de tratar al ser humano como un medio, se integra en los ordenamientos jurídicos mediante el derecho a la integridad moral.

No obstante, en contra de la integridad moral como el objeto tutelado en estas figuras delictivas también se alegan distintas razones. Entre ellas se sostiene que cualquier atentado contra la integridad moral implica la realización de conductas dirigidas a humillar y degradar a la persona, y ello no necesariamente sucede en los supuestos de trata de seres humanos ${ }^{25}$. Sin embargo, siendo definido el bien jurídico-penal "integridad moral" como la proscripción de una instrumentalización degradante de otro sin su consentimiento, que es como entiendo que debería definirse este interés, perfectamente podría considerarse protegido en los delitos de trata de seres humanos porque las conductas en ellos previstas orientadas a la explotación del sujeto pasivo implican, necesariamente, una cosificación humillante ${ }^{26}$.

El problema es que para amparar la integridad moral de las víctimas no hubiese sido necesaria en los delitos de trata de seres humanos la referencia a ciertos medios de determinación de su voluntad. Téngase en cuenta que las conductas que se prevén en estos delitos destinadas a las mismas finalidades de explotación en ellos contempladas, aunque supusiesen un ataque a la integridad moral de la víctima, no se podrían sancionar como

entender que estamos frente a un delito consumado basta que se verifiquen los verbos rectores con las circunstancias comisivas correspondientes, lo cual ciertamente produciría una lesión concreta de bienes jurídicos tales como la libertad ambulatoria y la seguridad personal (amenazas, uso de fuerza u otras formas de coacción)".

24 ALONSO ÁLAMO, Mercedes, “¿Protección penal de la dignidad? A propósito de los delitos relativos a la prostitución y a la trata de personas para la explotación sexual", Revista Penal, n 19 (2007), p. 6. Pérez Machío también concluye que no puede establecerse una relación de equivalencia entre dignidad e integridad moral que impida su diferenciación y conceptualización autónoma (PÉREZ MACHÍO, Ana Isabel, El delito contra la integridad moral del artículo 173.1 del vigente Código penal. Aproximación a los elementos que lo definen, Bilbao: Universidad del País Vasco, 2005, p. 161).

${ }^{25}$ Este motivo lo alega VILLACAMPA ESTIARTE, Carolina, "El delito de trata de seres humanos en el Código penal español”, en: LARA AGUADO, Ángeles (Dir.), Nuevos retos en la lucha contra la trata de personas con fines de explotación sexual. Un enfoque interdisciplinar, Pamplona: Aranzadi, 2012, p. 391.

${ }^{26}$ Sobre la integridad moral se habrían propuesto, según Villacampa Estiarte, tres definiciones. Así, de un lado, existiría aquella que la identifica con la idea de incolumnidad, siendo así que se define la integridad moral como el derecho a ser tratado como persona y no como cosa; de otro, la que acude para definir la integridad moral a referentes como la humillación y la degradación; y, finalmente, el grupo que vincula la integridad moral con la idea de quiebra de autonomía de la voluntad, es decir, exigiendo humillación y envilecimiento pero también la negación radical de la voluntad de la persona, en tanto que esencia de su libertad moral. Al respecto, VILLACAMPA ESTIARTE, El delito de trata de seres humanos, cit. nota $\mathrm{n}^{\circ} 12$, pp. 391 y 392. 
delitos de trata de seres humanos si se llevasen a cabo sin hacer uso de los medios comisivos establecidos. Es decir, por ejemplo, si un sujeto con ánimo de lucro convenciese a otro para que vendiese uno de sus riñones y lo trasladase al lugar donde va a realizarse la doble intervención ilegal, pero lo hiciese sin abusar de su situación ni emplear violencia, intimidación o engaño, entonces no sería responsable del delito de trata de seres humanos con fines de extracción de órganos, aunque se pueda entender que el donante ha sido degradado a la condición de cosa. Consecuentemente, la exigencia de que concurra alguno de los medios de determinación de la voluntad de la víctima tiene gran trascendencia en la concreción del bien jurídico protegido, pues parece impedir que la integridad moral sea el único interés tutelado en estos delitos.

\subsection{La libertad.}

La libertad es otro de los bienes jurídicos que los autores consideran protegido en los delitos de trata de seres humanos ${ }^{27}$.

El concepto de libertad es, como se sabe, amplísimo, relativo e indeterminado. Sin embargo, la libertad, como algo global y abstracto, carece de protección concreta tanto en el Código penal español como en el chileno. Sucede, en este caso, lo mismo que con la dignidad humana; la libertad es uno de los valores superiores del ordenamiento jurídico, pero no puede considerarse un bien jurídico-penal ${ }^{28}$. En la legislación penal de estos países se protegen sólo aspectos concretos de la libertad: la libertad deambulatoria, la libertad de decisión, la libertad de obrar, la libertad religiosa o de conciencia, la libertad sexual, etc. ${ }^{29}$.

\footnotetext{
${ }^{27}$ Partidario de esta tesis del bien jurídico protegido en el delito español de trata de seres humanos es BEDMAR CARRILLO, Eulogio, "El bien jurídico protegido en el delito de trata de seres humanos", La Ley Penal, no 94-95 (2012), pp. 82-95, pp. 90 y ss. Otros autores han considerado que la libertad es el objeto tutelado en el delito del artículo 177 bis del Código penal, aunque no de manera exclusiva. Entre ellos, MAPELLI CAFFARENA, "La trata de personas", cit. nota no 19, p. 51; y SANTANA VEGA, Dulce, "El nuevo delito de trata de seres humanos", Cuadernos de Política Criminal, no 104 (2011), pp. 79-108, p. 84. Y aluden a la libertad como uno de los bienes jurídicos protegidos en el delito del artículo 411 quater del Código penal chileno, por ejemplo, AGUILAR ARANELA, Cristian, Delitos sexuales. Tráfico ilícito de migrantes y trata de personas con fines de prostitución y explotación. Grooming, doctrina y jurisprudencia, Santiago de Chile: Ed. Metropolitana, 2012, p. 199; SOTO DONOSO, "Aspectos dogmáticos del delito de trata de personas", cit. nota $\mathrm{n}^{\circ}$ 9, p. 176; CARNEVALI, "La trata de personas y la normativa internacional.", cit. nota n ${ }^{\circ}$ 10, p. 182; GUZMÁN DALBORA, "La trata de seres humanos y el problema de su bien jurídico", cit. nota $n^{\circ}$ 23, p. 14; y RODRÍGUEZ PIZARRO, Ponencia en la mesa de trabajo "Migración, derechos humanos y ciudadanía", cit. nota no 10 . Conviene, asimismo, poner de manifiesto que, en la mayoría de los países, los delitos de trata de seres humanos se ubican entre los delitos contra la libertad individual. Esto sucede, por ejemplo, en Alemania, Portugal, Italia, Brasil o Costa Rica.

${ }^{28}$ Asimismo, se considera que si de la dignidad se dice que todos los delitos la afectan de una u otra forma, debería decirse lo mismo de la libertad. Sobre este inconveniente, GARCÍA ARÁN, "Esclavitud y tráfico de seres humanos", cit. nota $n^{\circ} 15$, p. 377.

${ }^{29}$ En el Derecho penal comparado suelen distinguirse claramente dos aspectos: la libertad como estado, que se refiere a la propia personalidad individual, como requisito esencial e inalienable del hombre; y la libertad como facultad, que se refiere a ciertas manifestaciones de la libertad. Pues bien, la primera de estas facetas se protegería en el delito de esclavitud; mientras que en España y en Chile sólo se ha considerado un bien jurídico digno de protección penal la libertad como facultad. Véase, sobre estas distintas manifestaciones de la libertad, CAMAÑO ROSA, Antonio, "Delitos contra la libertad", Anuario de Derecho penal y ciencias penales, Tomo 20 (1967), p. 57-95.
} 
MOYA, Clara. "Los delitos de trata de seres humanos en España y Chile. Bien jurídico protegido y relaciones concursales".

A pesar de tal restricción, para quienes defienden que la libertad es el objeto amparado en los delitos de trata de seres humanos existen diversos argumentos que respaldan una concepción de estas características. Alegan, fundamentalmente, que en la captación, así como también en el transporte o en el traslado, se disipa la libertad deambulatoria de la víctima; y, más adelante, en sucesivas fases de recepción o alojamiento, esta pierde su libertad de obrar, su libertad de decisión; en suma, su libertad de autodeterminación personal. También a favor de este bien jurídico arguyen que los delitos de trata de seres humanos no exigen la efectiva ejecución de ningún fin de explotación, sino que basta con la intención de llevarlo a cabo para que se consideren consumados. Por ello, entiende Bedmar Carrillo que:

"si partimos de esta base, resulta algo más complicado defender la dignidad como bien jurídico de este delito y la integridad como su manifestación última y material, ya que, si relacionamos la vulneración de estos conceptos con la acción de cosificación de la persona, con su instrumentalización y posterior negocio con ella, que es cuando se completa la destrucción de los mismos, sería muy difícil que llegara a darse si no se materializa de manera completa la efectiva explotación",30.

Por estos motivos, el mencionado autor llega a la conclusión de que, en realidad, el interés que se ampara mediante la incriminación de la trata de seres humanos es la libertad, entendida en un sentido amplio, que él define como "la defensa de cualquier resquicio en que la persona sea privada de su propia autonomía y de su propia toma de decisiones" 31 . Parece, entonces, que este autor identifica la libertad amparada en los delitos de trata de seres humanos con la "libertad general de acción" 32 , que ni en España ni en Chile se configura como un bien jurídico-penal; pero, este autor, en realidad, argumenta que dicho status libertatis se protege, en estas figuras delictivas, mediante las distintas manifestaciones jurídico-penalmente protegidas de la libertad (concretamente, alude a la libertad deambulatoria, a la libertad de decisión y a la libertad de obrar).

En contra de esta opción, sin embargo, se sostiene que los actos de trata de seres humanos suponen algo más que un mero ataque a la libertad; conllevan un ataque diverso que justifica su criminalización a través de una prohibición autónoma y diferente de los delitos contra la libertad. En este sentido, Daunis Rodríguez considera que con las conductas de trata de seres humanos se produce una instrumentalización de la víctima que no está necesariamente presente en los ataques a la libertad de la persona ${ }^{33}$.

\footnotetext{
${ }^{30}$ BEDMAR CARRILLO, "El bien jurídico protegido en el delito de trata de seres humanos", cit. nota $\mathrm{n}^{\mathrm{o}} 27$, pp. 91-92.

${ }^{31}$ BEDMAR CARRILLO, "El bien jurídico protegido en el delito de trata de seres humanos", cit. nota $\mathrm{n}^{\circ} 27$, p. 92. Igualmente, Guzmán Dalbora, en relación con el delito del artículo 411 quater del Código penal chileno, sostiene que el objeto de tutela se refiere a la persona convertida en víctima del tráfico, a su individualidad y, por ende, a la salvaguarda del presupuesto de esta última: la autodeterminación. Al respecto, GUZMÁN DALBORA, "La trata de seres humanos y el problema de su bien jurídico", cit. nota no 23, p. 14.

${ }^{32}$ Acerca de la libertad general de actuación en la Ley Fundamental alemana, véase BÖSE, Martin, "Derechos fundamentales y Derecho penal como Derecho coactivo", en: HEFENDEHL, Roland (Ed.), La teoría del bien jurídico, ifundamento de legitimación del derecho penal o juego de abalorios dogmático?, Madrid: Marcial Pons, 2007, pp. 137-146.

${ }^{33}$ DAUNIS RODRÍGUEZ, El delito de trata de seres humanos, cit. nota ${ }^{\circ} 12$, pp. 77 y 78 . Por su parte, Villacampa Estiarte se opone a esta consideración porque entiende que "la libertad en este contexto no debe
} 


\section{Polít. crim. Vol. 11, No 22 (Diciembre 2016), Art. 6, pp. 521-547. \\ [http://www.politicacriminal.cl/Vol_11/n_22/Vol11N22A6.pdf]}

Y, precisamente por esta razón, también descarto que la libertad se erija en el único bien jurídico protegido en los delitos de trata de seres humanos.

\subsection{La libertad, la dignidad y otros bienes jurídico-penales. Los delitos de trata de seres humanos como delitos pluriofensivos.}

Finalmente, en relación con el objeto tutelado en los delitos de trata de seres humanos, un amplio sector doctrinal considera que se protegen diversos bienes simultáneamente ${ }^{34}$. No obstante, mientras algunos autores partidarios de esta postura estiman que se amparan de manera conjunta la libertad y la dignidad de la víctima; otros, añaden a alguno de estos intereses o a ambos, otros bienes que también se tutelarían indirectamente mediante la incriminación de la trata de seres humanos ${ }^{35}$.

Quienes sostienen que se pretenden proteger, al mismo tiempo, la dignidad (o, en su caso, la integridad moral) y la libertad del sujeto pasivo estiman que los delitos de trata de seres humanos sancionan el ataque al primer bien jurídico-penal, en la medida en que la instrumentalización del ser humano para la consecución de determinadas finalidades mercantilistas supone generarle una situación humillante; pero, entienden que, igualmente,

ser identificada con la libertad de obrar en un concreto supuesto, sino con la alojada en la propia base de la persona en tanto que persona, con la libertad como valor caracterizador de la condición de humano y, por tanto, como integrante de la misma dignidad" (VILLACAMPA ESTIARTE, El delito de trata de seres humanos, cit. nota $\mathrm{n}^{\circ} 12$, p. 406).

${ }^{34}$ MARAVER GÓMEZ, Mario, “Trata de seres humanos”, en: MOLINA FERNÁNDEZ, Fernando (Coord.), Memento penal 2016, Madrid: Francis Lefebvre, 2015, pp. 944-958, p. 944; MUÑOZ CONDE, Francisco, Derecho penal. Parte especial, Valencia: Tirant lo Blanch, 2015, p. 169; SANTANA VEGA, Dulce, "Artículo 177 bis del Código penal", en: CORCOY BIDASOLO, Mirentxu (Dir.), Manual de Derecho penal. Parte especial. Tomo 1, Valencia: Tirant lo Blanch, 2015, pp. 192-206, p. 178; REQUEJO NAVEROS, María Teresa, "El delito de trata de seres humanos en el Código penal español: Panorama general y compromisos internacionales de regulación", en: ALCÁCER GUIRAO, Rafael, MARTÍN LORENZO, María y VALLE MARISCAL DE GANTE, Margarita (Coords.), La trata de seres humanos: Persecución penal y protección de las víctimas, Madrid: Edisofer, 2015, pp. 19-56, p. 29; CANO PAÑOS, Miguel Ángel, "De la trata de seres humanos", en: MORILLAS CUEVA, Lorenzo (Dir.), Estudios sobre el Código penal reformado, Madrid: Dykinson, 2015, pp. 421-432, p. 423; OLAIZOLA NOGALES, Inés, “A vueltas con la inmigración ilegal y el nuevo delito de trata de personas", en: FERNÁNDEZ TERUELO, Javier Gustavo (Dir.), Estudios penales en homenaje al profesor Rodrigo Fabio Suárez Montes, Oviedo: Editorial Constitutio Criminalis Carolina, 2013, pp. 459-489, p. 472; MAPELLI CAFFARENA, "La trata de personas", cit. nota $\mathrm{n}^{\circ}$ 19, p. 51; POMARES CINTA, Esther, "El delito de trata de seres humanos con finalidad de explotación laboral", Revista Electrónica de Ciencias Penales y Criminología, no 13-15 (2011); AGUILAR ARANELA, Delitos sexuales. Tráfico ilícito de migrantes y trata de personas con fines de prostitución y explotación, cit. nota $\mathrm{n}^{\circ}$ 27, p. 199; SOTO DONOSO, "Aspectos dogmáticos del delito de trata de personas", cit. nota $\mathrm{n}^{\circ}$ 9, p. 176; CARNEVALI, "La trata de personas y la normativa internacional. Algunas consideraciones de su regulación en Chile", cit. nota ${ }^{\circ}$ 10, p. 182; GUZMÁN DALBORA, "La trata de seres humanos y el problema de su bien jurídico", cit. nota $\mathrm{n}^{\circ}$ 23, p. 14; y RODRÍGUEZ PIZARRO, Ponencia en mesa de trabajo "Migración, derechos humanos y ciudadanía", cit. nota $\mathrm{n}^{\circ} 10$.

${ }^{35}$ En este sentido, conviene poner de manifiesto que en la Sentencia 199/2012, de 7 de septiembre, del Cuarto Tribunal de Juicio Oral en lo Penal de Santiago, se destaca el "carácter pluriofensivo del delito, por la multiplicidad de bienes jurídicos que protege, entre otros, la vida e integridad, libertad y seguridad personal, y libertad sexual y de trabajo". Y en la Sentencia 293/2013, de 2 de noviembre, dictada por este mismo tribunal, se estima que se trata de un "delito pluriofensivo que lesiona una gama de bienes jurídicos, tales como la vida y la integridad física, la libertad y seguridad de las personas, la libertad e indemnidad sexual, la libertad de tránsito y residencia, la libertad de trabajo y la honra de las personas". 
MOYA, Clara. "Los delitos de trata de seres humanos en España y Chile. Bien jurídico protegido y relaciones concursales".

se castiga el ataque a la libertad, porque se doblega la voluntad del sujeto pasivo para alcanzar dichos fines ${ }^{36}$.

Por su parte, los autores partidarios de la perspectiva pluriofensiva de estos delitos, en la segunda variante indicada, advierten, además de lo anterior, que se ha considerado merecedora de pena únicamente la trata de seres humanos que va dirigida a determinadas formas de explotación. Esto indicaría, según argumentan, que puesto que sólo se castigan las conductas de trata de seres humanos cuando van dirigidas a la consecución de ciertos fines, están tratando de protegerse, junto a los bienes jurídicos directamente afectados (la dignidad y/o la integridad moral de la víctima y/o su libertad), otros bienes jurídico-penales que este fenómeno pone en peligro en función de la explotación que se persiga. De este modo, según Mapelli Caffarena,

"allá donde haya una trata, conforme a lo que tipifica el Código, habrá, cuando menos, una lesión a la libertad ambulatoria y un peligro para otros bienes jurídicos en función de la naturaleza del traslado. En correspondencia a los dos ejes sobre los que gira el injusto podemos hablar también de un delito pluriofensivo; siempre se verá comprometida la libertad y a ello habrá que sumar la lesión o puesta en peligro de otros bienes jurídicos determinados por las condiciones del traslado. Pero el elemento subjetivo trascendente del objetivo del traslado añade como bien jurídico la puesta en peligro de los derechos de la víctima afectados por la explotación"37.

Y Soto Donoso va más allá al afirmar que "las hipótesis de explotación que contempla la norma no son requeridas para la consumación, por lo que respecto de los bienes jurídicos involucrados en ellas (libertad sexual, libertad laboral, vida e integridad física), así como respecto de la noción de dignidad humana [...], habría sólo un peligro de lesión" 38 .

Quienes se oponen a esta última tesis, en cambio, afirman que el bien jurídico protegido en los delitos de trata de seres humanos debería ser independiente de los que puedan resultar afectados a través de la ejecución de las distintas finalidades de explotación, pues no es necesario que la explotación llegue a término para entender consumados los delitos de trata de seres humanos y, además, porque si no estos perderían su razón de $\operatorname{ser}^{39}$.

Sin embargo, a mi juicio, la aceptación de los referidos intereses como bienes jurídicos protegidos en los delitos de trata de seres humanos no niega la autonomía de estas figuras delictivas respecto de los delitos de explotación, pues, aunque en estos últimos se sancione la efectiva lesión de los mismos objetos tutelados que en los delitos de trata de seres humanos se ponen en peligro, en los de trata de seres humanos también se protegerían otros

\footnotetext{
${ }^{36}$ Por este motivo, afirma Muñoz Conde, en relación con el delito del artículo 177 bis del Código penal, que aunque la razón de la incriminación autónoma de la trata de seres humanos tendría más que ver con la integridad moral, esta se lesionaría a través de diversas formas de atentado a la libertad (MUÑOZ CONDE, Derecho penal. Parte especial, cit. nota $\mathrm{n}^{\circ} 34$, p. 154). En el mismo sentido, REQUEJO NAVEROS, "El delito de trata de seres humanos en el Código penal español”, cit. nota n ${ }^{\circ} 34$, p. 29.

${ }^{37}$ MAPELLI CAFFARENA, "La trata de personas", cit. nota no 19, p. 51.

${ }^{38}$ SOTO DONOSO, “Aspectos dogmáticos del delito de trata de personas", cit. nota n 9, p. 176.

${ }^{39}$ En este sentido, REQUEJO NAVEROS, "El delito de trata de seres humanos en el Código penal español", cit. nota n ${ }^{\circ}$ 34, p. 34; y VILLACAMPA ESTIARTE, “Título VII bis", cit. nota n 16, p. 283.
} 
intereses, que se verían directamente lesionados (la dignidad y/o la integridad moral y/o la libertad). Por esta razón, no comparto que los delitos de trata de seres humanos pierdan su razón de ser si se entiende que son delitos pluriofensivos en el sentido apuntado, ya que los delitos de explotación no abarcarían completamente el desvalor de los delitos de trata de seres humanos.

\subsection{Toma de postura.}

Considerando las distintas posturas doctrinales examinadas acerca del bien jurídico protegido en los delitos de trata de seres humanos, en los siguientes epígrafes, voy a explicar los motivos que me llevan a concluir que estos tipos penales son pluriofensivos. Para ello, por un lado, indicaré las razones por las que sostengo que existe un bien jurídico común a todas las modalidades delictivas de la trata de seres humanos (es decir, común a la trata de seres humanos con fines de explotación laboral, de explotación sexual y de extracción de órganos ${ }^{40}$ ) y señalaré cuál es o, en su caso, cuáles son; y, por otro lado, explicaré las razones que me llevan a entender que existen también otros objetos tutelados en estos delitos, distintos en cada una de las modalidades delictivas enumeradas.

\subsubsection{Bienes jurídico-penales comunes en todas las modalidades delictivas.}

Comenzando por el primero de los análisis anunciados, la existencia de un bien jurídico común en todas las modalidades delictivas de la trata de seres humanos resulta obvia, puesto que comparten, además de la ubicación sistemática, las conductas típicas, los medios de determinación de la voluntad de la víctima y las penas a imponer. Por este motivo, es decir, porque actualmente se otorga un tratamiento uniforme a las distintas modalidades delictivas de la trata de seres humanos, se puede deducir que se persigue la protección de un mismo bien jurídico, con independencia de que en cada una de ellas se tutele, a su vez, otro interés.

Asumiendo, pues, la existencia de un objeto de tutela común a todas las modalidades delictivas de la trata de seres humanos, es momento de determinar cuál es. Para ello, de forma previa, conviene recordar que la trata de seres humanos, como su propio nombre indica $^{41}$, consiste en la conversión de la persona en cosa u objeto de intercambio o disposición plena por parte de su propietario o poseedor. Esta relación fáctica de dominio, que es la que permite al tratante gozar y disponer de la víctima como si se tratara de un bien de su propiedad ${ }^{42}$, es la que dota de singularidad al fenómeno y, en definitiva, la que justifica que se le dé un tratamiento jurídico-penal autónomo. Pues bien, habiendo descartado que la dignidad humana pueda considerarse un bien jurídico-penal en los ordenamientos español y chileno, debe acudirse al bien jurídico-penal "integridad moral" para incorporar al injusto de estos delitos la proscripción de instrumentalizar a la víctima de manera degradante.

\footnotetext{
${ }^{40}$ Voy a referirme exclusivamente a estas tres modalidades delictivas de la trata de seres humanos porque son las comunes a los delitos español y chileno.

${ }^{41}$ El Diccionario de la RAE define la "trata" como el "tráfico que consiste en vender seres humanos como esclavos".

${ }^{42}$ Sobre el fenómeno de la trata de seres humanos, PÉREZ ALONSO, Esteban Juan, Tráfico de personas e inmigración clandestina, Valencia: Tirant lo Blanch, 2008, p. 177.
} 
MOYA, Clara. "Los delitos de trata de seres humanos en España y Chile. Bien jurídico protegido y relaciones concursales".

Como avanzaba con anterioridad, a pesar de las diversas definiciones que la doctrina ha elaborado sobre el bien jurídico-penal "integridad moral", entiendo que la más adecuada, por razones cuya explicación excedería del propósito del presente trabajo, es la prohibición de instrumentalizar de un modo vejatorio a una persona sin su consentimiento. Siendo este el significado del objeto de tutela "integridad moral" y asumiendo que, a diferencia de la dignidad, es un bien jurídico-penal tanto en el ordenamiento español como en el chileno, parece indiscutible que en los delitos de trata de seres humanos se erige en uno de los objetos amparados.

Sin embargo, como también apuntaba supra, los delitos de trata de seres humanos no prohíben sólo la cosificación degradante de la víctima sino que, además, impiden que se determine su voluntad hacia alguno de los fines de explotación previstos. Por esta razón, resulta inevitable incorporar la "libertad" al elenco de bienes jurídicos que se protegen en estas figuras delictivas. En particular, puesto que la libertad, como estado, tampoco se tutela jurídico-penalmente ni en el ordenamiento español ni en el chileno, la libertad amparada en los delitos de trata de seres humanos sería la libertad de decisión, la libertad de acción o la libertad deambulatoria.

Pues bien, bajo mi punto de vista, al prohibir la trata forzada (con violencia o intimidación) de seres humanos se ampararía, concretamente, la libertad de obrar; es decir, el mismo bien jurídico tutelado en los delitos de coacciones ${ }^{43}$. Adviértase que los delitos de trata forzada de seres humanos comparten el fundamento de los de coacciones; el núcleo central de ambos consiste en imponer con violencia una conducta a otro a través de diversas modalidades de actuación ${ }^{44}$. Por su parte, con la incriminación de la trata fraudulenta o abusiva de seres humanos se tutelaría la libertad de decisión, ya que mediante el engaño, así como también abusando de la situación de necesidad o de vulnerabilidad de la víctima, o aprovechándose de una situación superioridad, se interfiere, sin duda alguna, en el proceso deliberativo de este sujeto $^{45}$. Pero, en cualquier caso, dado que se han equiparado todas estas formas de comisión de la trata de seres humanos, entiendo que los tipos penales en los que se prevén protegen la libertad de autodeterminación del sujeto pasivo, sin necesidad de concretar si se tutela en la fase de formación de la voluntad o en la fase de ejecución. Lo que descartaría es que la libertad deambulatoria de la víctima sea uno de los objetos tutelados en los delitos de trata de seres humanos, pues resulta perfectamente posible

\footnotetext{
${ }^{43}$ El empleo de la violencia en este tipo de contextos afecta a la libertad de obrar. Afirma, por ello, Queralt Jiménez que "el bien jurídico que se protege en las coacciones es la libertad de obrar de las personas, sin necesidad de afectar su proceso de motivación” (QUERALT JIMÉNEZ, Derecho penal español. Parte especial, cit. nota $\mathrm{n}^{\mathrm{o}} 12$, p. 145).

${ }^{44}$ Considera Quintero Olivares que en los delitos contra la libertad son elementos esenciales la intención de doblegar la voluntad de la víctima y el uso de la violencia o la intimidación por parte del autor para realizar su acción (QUINTERO OLIVARES, Gonzalo, Comentarios a la Parte especial del Derecho penal, Pamplona: Aranzadi, 2011, p. 211). Pues bien, estos son también los elementos que configuran los delitos de trata forzada de seres humanos.

${ }^{45}$ Para la doctrina mayoritaria el bien jurídico protegido en los delitos de amenazas es la libertad en la formación de la voluntad. Es, particularmente, la libertad de motivación del sujeto pasivo la que se ampara, pues este tiene derecho a que en los procesos de formación de su voluntad no se interpongan presiones intolerables más allá de lo socialmente admitido. Véase, al respecto, MIRA BENAVENT, Javier, "El concepto de violencia en el delito de coacciones", Cuadernos de Política Criminal, no 22 (1984), pp. 95-182.
} 


\section{Polít. crim. Vol. 11, № 22 (Diciembre 2016), Art. 6, pp. 521-547. \\ [http://www.politicacriminal.cl/Vol_11/n_22/Vol11N22A6.pdf]}

consumarlos sin que se afecte de ninguna manera esta facultad. Así pues, habrá que apreciar un delito de detenciones ilegales si concurren sus elementos ${ }^{46}$.

En suma, en los delitos de trata de seres humanos se tutelan tanto la integridad moral del sujeto pasivo como su libertad de autodeterminación.

\subsubsection{Bienes jurídico-penales distintos en cada una de las modalidades delictivas.}

La determinación de que la integridad moral de la víctima y su libertad de autodeterminación son bienes jurídicos amparados en los delitos de trata de seres humanos es una conclusión que podría justificar, por sí sola, la prohibición penal autónoma de este fenómeno. Sin embargo, otras razones ponen en duda que sólo sean estos los objetos amparados en las figuras delictivas que recogen dicha prohibición. Así, la alusión en ambos preceptos a la "víctima" (en singular) frente a la referencia en los respectivos títulos donde se ubican estos delitos a los "seres humanos" o "personas" (en plural) y en una de las conductas típicas que estos tipos penales prevén a "personas" (también en plural) insinuarían que no sólo se protegen bienes jurídicos individuales, como los que acabo de establecer, sino que también se tutelan, al menos en algunos casos, bienes jurídicos colectivos $^{47}$. Y a la conclusión de que en estos delitos se protegen bienes jurídico-penales distintos de la integridad moral y la libertad de autodeterminación de la víctima también llevaría la previsión de tan elevadas penas ${ }^{48}$. No obstante, que los delitos de trata de seres humanos deben estar protegiendo otros intereses se confirma, de una manera más evidente, como seguidamente voy a tratar de justificar, en el hecho de que los legisladores penales nacionales hayan establecido un numerus clausus de finalidades de explotación.

En relación con este último motivo, conviene recordar que en el artículo 3 del Protocolo de Palermo se exige la incriminación de la trata de seres humanos "con fines de explotación". Este precepto continua indicando que "esa explotación incluirá, como mínimo, la explotación de la prostitución ajena u otras formas de explotación sexual, los trabajos o

\footnotetext{
${ }^{46}$ El Tribunal Supremo español considera, en ocasiones, que la detención ilegal absorbe el delito contra la integridad moral (entre otras, véase, en este sentido, la STS 505/2005, de 14 de abril). No obstante, la STS 101/2007, de 7 de febrero, afirmó que es perfectamente compatible el delito de detenciones ilegales y los delitos contra la integridad moral, siempre que el atentado contra la integridad moral suponga un plus respecto de los delitos de detenciones ilegales.

47 El artículo 177 bis del Código penal español, ubicado en un título denominado "De la trata de seres humanos" castiga al que, empleando violencia, intimidación o engaño, o abusando de una situación de superioridad o de necesidad o de vulnerabilidad de la víctima nacional o extranjera, o mediante la entrega o recepción de pagos o beneficios para lograr el consentimiento de la persona que poseyera el control sobre la víctima, la captare, transportare, trasladare, acogiere, o recibiere, incluido el intercambio o transferencia de control sobre esas personas. Por su parte, el artículo 411 del Código penal chileno, ubicado entre los delitos "de tráfico ilícito de inmigrantes y trata de personas" sanciona al que mediante violencia, intimidación, coacción, engaño, abuso de poder, aprovechamiento de una situación de vulnerabilidad o de dependencia de la víctima, o la concesión o recepción de pagos u otros beneficios para obtener el consentimiento de una persona que tenga autoridad sobre otra capte, traslade, acoja o reciba personas para que sean objeto de alguna forma de explotación.

48 Adviértase, por ejemplo, que el límite máximo de la pena de prisión prevista en el delito español de coacciones (art. 172.1 C.p.) sumado al establecido en el delito contra la integridad moral del artículo 173.1 del Código penal serían 5 años y este, en cambio, es el límite mínimo de la pena de prisión prevista en el delito de trata de seres humanos, mientras que su límite máximo se sitúa en los 8 años.
} 
MOYA, Clara. "Los delitos de trata de seres humanos en España y Chile. Bien jurídico protegido y relaciones concursales".

servicios forzados, la esclavitud o las prácticas análogas a la esclavitud, la servidumbre o la extracción de órganos". Desde el Derecho internacional se pretende, de este modo, que se incrimine la trata de seres humanos cualquiera que sea la finalidad de explotación perseguida $^{49}$; y, si dicha incriminación no resulta conveniente, se requiere que, al menos, se tipifique la trata de seres humanos que tenga por objetivo la explotación laboral, la explotación sexual o la extracción de órganos. Sin embargo, ni el legislador penal español ni el chileno han escogido la opción prioritaria del Protocolo de Palermo y han sancionado la trata de seres humanos sólo cuando se persiguen determinadas formas de explotación.

Los fines que, específicamente, deben buscarse para poder considerar consumado el delito español de trata de seres humanos son, tras la modificación operada por la Ley Orgánica 1/2015: la denominada "explotación laboral"50, la explotación sexual, la extracción de órganos, la explotación para realizar actividades delictivas y la celebración de matrimonios forzados. Y para apreciar el delito chileno de trata de seres humanos deben perseguirse alguno de estos fines: la explotación sexual, la denominada "explotación laboral"51 o la extracción de órganos.

La previsión de estas concretas finalidades de explotación (y, por ende, la exclusión de los tipos penales de la trata de seres humanos con otros fines de explotación, como la orientada a la adopción ilegal de menores, a la experimentación científica no consentida con seres humanos, a la recluta de niños para desarrollar actividades militares, etc.) y el resto de los argumentos expuestos me llevan a deducir que la prohibición penal de la trata de seres humanos, no sólo busca la tutela de la integridad moral del sujeto pasivo y de su libertad de

\footnotetext{
${ }^{49}$ De una forma mucho más inequívoca, en España, algunos autores recomendaron incriminar la trata de seres humanos con cualquier finalidad de explotación. Por ejemplo, Cobos Gómez de Linares proponía que se modificasen los apartados a), b) y c) del artículo 177 bis.1 del Código penal por el siguiente texto: “o de cualquier forma la mantuviere bajo su control o la transfiriere a un tercero con la finalidad de aprovecharse sexual o económicamente de la víctima" (en COBOS GÓMEZ DE LINARES, Miguel Angel, "Trata de seres humanos: art. 177 bis C.p.”, en: ÁLVAREZ GARCÍA, Francisco Javier (Dir.), Estudio crítico sobre el Anteproyecto de Reforma penal de 2012, Valencia: Tirant lo Blanch, 2013, p. 622).

${ }^{50}$ Aunque la modalidad delictiva prevista en el apartado a) del primer inciso del artículo 177 bis del Código penal se conoce como "trata de seres humanos con fines de explotación laboral", la explotación laboral no puede quedar enmarcada dentro de la esclavitud o prácticas similares, la servidumbre ni, por supuesto, la mendicidad. Por ello, únicamente restaría la posibilidad de subsumir la explotación laboral dentro de la vertiente del trabajo o servicios forzados, aunque ello, lógicamente, presenta ciertas dificultades. A este respecto, recuerda Cano Paños que la jurisprudencia española no ha aplicado el delito de trata de seres humanos cuando la finalidad de la conducta es la explotación laboral. Así pues, la imposición, por ejemplo, de jornadas laborales extenuantes, sin periodos de descanso, con escasa o incluso nula remuneración representa una situación que no siempre es susceptible de quedar subsumida dentro de la categoría de los trabajos o servicios forzados. Al respecto, véase CANO PAÑOS, "De la trata de seres humanos", cit. nota n 33, pp. 425 y 426 .

${ }^{51}$ En este ámbito, conviene poner de manifiesto que el Tribunal Constitucional de Chile, el 30 de octubre de 2014, dictó una sentencia en la que confirmó la constitucionalidad del término "o prácticas análogas a estas" del artículo 411 quater del Código penal. El Tribunal rechazó que esta expresión vulnerase el principio de tipicidad porque existe un verbo rector inequívoco: “esclavizar". Por ello, entendió que no cabe duda de que lo que se pretende es reprimir la práctica de la esclavitud, en todas sus formas. Así, concluyó que en el estado actual de conciencia jurídica universal no resulta difícil discernir qué es la esclavitud en sentido estricto o en sus formas análogas, o (también así llamadas) modernas. Sin embargo, en la Sentencia 31/2015, de 8 de junio, del Tribunal de Juicio Oral en lo Penal de Santa Cruz, se consideró que la trata de seres humanos con fines de explotación laboral no estaba tipificada en el delito previsto en el artículo 411 quater del Código penal.
} 


\section{Polít. crim. Vol. 11, No 22 (Diciembre 2016), Art. 6, pp. 521-547. \\ [http://www.politicacriminal.cl/Vol_11/n_22/Vol11N22A6.pdf]}

autodeterminación, sino que, además, pretende amparar otros intereses que se ponen en peligro con estos comportamientos y que se han estimado especialmente relevantes.

Así, por ejemplo, mediante la incriminación de la denominada "trata de seres humanos con fines de explotación laboral" se pretenderían resguardar, de manera anticipada, los derechos laborales de los trabajadores; en el delito de trata de seres humanos con fines de explotación sexual el bien jurídico protegido mediatamente sería la libertad sexual de la víctima; y en el delito de trata de seres humanos con fines de extracción de órganos, aunque la doctrina mayoritaria estima que el objeto tutelado es la salud del donante ${ }^{52}$, el bien jurídico protegido sería la salud pública ${ }^{53}$.

En conclusión, los delitos de trata de seres humanos deben suponer, en todo caso, además de la lesión de la integridad moral de la víctima y de su libertad de autodeterminación, la puesta en peligro de alguno de los bienes jurídico-penales señalados, según la modalidad delictiva de la que se trate, porque también estos conforman los tipos penales.

\section{La relación concursal entre los delitos de trata de seres humanos y los delitos que sancionan la explotación que con ella se persigue.}

La conclusión acerca del bien jurídico protegido en los delitos de trata de seres humanos, evidentemente, tiene importantes repercusiones dogmáticas. Entre ellas, adquiere especial relevancia la determinación de la relación concursal existente entre estas figuras delictivas y los delitos que sancionan, de algún modo, la explotación que con la trata de seres humanos se persigue (delitos contra los derechos de los trabajadores, delitos contra la libertad sexual o delitos de tráfico de órganos humanos $)^{54}$. Tal importancia viene dada por la frecuencia con la que se enjuician los casos de trata de seres humanos cuando la víctima ya ha sido explotada ${ }^{55}$.

\footnotetext{
52 Entre ellos, MARTOS NÚÑEZ, "El delito de trata de seres humanos: análisis del artículo 177 bis del Código penal", cit. nota $\mathrm{n}^{\circ}$ 22, p. 100; SANTANA VEGA, "El nuevo delito de trata de seres humanos", cit. nota $n^{\circ} 27$, p. 84; y SOTO DONOSO, “Aspectos dogmáticos del delito de trata de personas del artículo $3^{\circ}$ del Protocolo de Palermo", cit. nota $n^{\circ}$ 9, p. 176.

${ }^{53} \mathrm{Si}$ la salud del donante fuese la razón de tal incriminación se hubiese tipificado, en general, la trata de seres humanos para la explotación fisionómica de las víctimas; es decir, para la extracción de tejidos, para la utilización del útero de personas tratadas para gestar hijos biológicos de otras personas, para efectuar sobre las mismas ensayos clínicos o farmacológicos, para la extracción de sangre con la finalidad de venderla, etc. Por ello, esta previsión sólo tiene sentido en cuanto que la extracción del órgano de la víctima vaya a comercializarse con fines terapéuticos, ya que sólo entonces puede afirmarse que el sujeto pasivo ha sido cosificado o instrumentalizado con fines mercantilistas.

${ }^{54}$ Téngase en cuenta que sólo se planteará este conflicto de normas cuando un mismo sujeto intervenga en la trata de seres humanos y posteriormente en los actos de explotación que con la trata de seres humanos se pretendían. Como explica Mapelli Caffarena, son imaginables dos supuestos que merecen el mismo tratamiento, aunque por distintas vías. El primero, cuando los propios individuos se hacen responsables del traslado de la víctima y su posterior explotación; y, el segundo, cuando la explotación la realizan terceras personas (supuesto relativamente frecuente, según la información criminológica). Al respecto, MAPELLI CAFFARENA, "La trata de personas", cit. nota n' 19, p. 58.

${ }^{55}$ En España, por ejemplo, todos los casos que ha conocido el Tribunal Supremo o alguna de las Audiencias Provinciales sobre los que ha recaído sentencia condenatoria en virtud del artículo 177 bis del Código penal han llegado al conocimiento de las autoridades cuando la víctima ya había sido explotada. Véanse, en este sentido, la Sentencia de la AP de Madrid 261/2014, de 12 de junio; la Sentencia del TS 1851/2014, de 4 de
} 
MOYA, Clara. "Los delitos de trata de seres humanos en España y Chile. Bien jurídico protegido y relaciones concursales".

Pues bien, mientras hay quienes entienden que entre los delitos de trata de seres humanos y los que materializan la explotación que con la trata de seres humanos se pretende existe un concurso de normas; otros sostienen que se da un concurso de delitos, debatiendo entonces si se trata de un concurso real, medial o ideal ${ }^{56}$.

A mi juicio, sin embargo, no debería ofrecerse una única respuesta a estos problemas concursales. Para solucionar la concurrencia de normas penales en este ámbito habría que distinguir dos supuestos distintos que se resolverían también de manera diferente.

Así, entre el delito de trata de seres humanos que, además de lesionar la integridad moral y la libertad de autodeterminación de la víctima, pone en peligro un bien jurídico-penal y aquel otro que sanciona su efectiva lesión existiría, en principio, un concurso real de delitos, pues estaríamos en presencia de dos hechos perfectamente diferenciados: la trata de seres humanos y la posterior explotación, que se sancionan en figuras delictivas distintas que no protegen el mismo bien jurídico-penal. Esta sería la solución que podría ofrecerse en caso de conflicto, por ejemplo, entre el delito de trata de seres humanos con fines de explotación sexual (cuya ejecución pone en peligro la libertad sexual de la víctima, además de lesionar su integridad moral y su libertad de autodeterminación) y el delito de prostitución coactiva (cuya comisión lesiona la libertad sexual de la víctima). Sin embargo, en un supuesto como este, la efectiva explotación (en este caso, sexual) de la víctima se erigiría, en cierto modo, en un agotamiento de la conducta de trata de seres humanos con fines de explotación sexual, por lo que podría estimarse la presencia de un delito instrumento y un delito fin. De este modo, en la mayoría de estos casos podría resultar de aplicación la regla del concurso medial de delitos ${ }^{57}$.

febrero; la Sentencia del TS 910/2013, de 3 de diciembre; la Sentencia de la AP de Cádiz 206/2013, de 28 de junio; la Sentencia de la AP de Madrid 153/2013, de 8 de marzo; y la Sentencia de la AP de Barcelona 9/2013, de 6 de febrero.

${ }^{56}$ Como se sabe, se habla de "concurso de normas penales" para designar la situación que se crea cuando de un mismo hecho, constitutivo de una sola infracción, se ocupan dos preceptos (o más) y aparentemente ambos le son aplicables, aunque sólo uno lo es. En cambio, en el concurso de delitos el desvalor del hecho no se agota con la aplicación de una ley, siendo precisa más de una para que el referido desvalor resulte plenamente abarcado. Véase, acerca del concurso de normas y sus diferencias con el concurso de delitos, CASTELLÓ NICÁS, Nuria, El concurso de normas penales, Granada: Comares, 2000, pp. 49 y ss.; y GARCÍA ALBERO, Ramón, "Non bis in idem" material y concurso de leyes penales, Barcelona: Cedecs, 1995.

${ }^{57}$ Partidaria de esta solución es, por ejemplo, OLAIZOLA NOGALES, “A vueltas con la inmigración ilegal y el nuevo delito de trata de personas", cit. nota $n^{\circ} 34$, p. 488. En este sentido, la Sentencia del TS español 1851/2014, de 4 de febrero, determina la existencia de un concurso medial entre el delito de trata de seres humanos con fines de explotación sexual y el delito de prostitución coactiva bajo los siguientes razonamientos: "Nos encontramos, en consecuencia, ante un concurso de delitos y no un concurso de leyes, pues aun cuando la finalidad de explotación sexual constituye un elemento del tipo del artículo 177 bis, la sanción por este delito no absorbe toda la gravedad de la conducta realizada, cuando dicha explotación se llega a consumar efectivamente. Pero lo cierto es que la trata de seres humanos con fines de explotación sexual constituye una acción preparatoria de la explotación posterior, explotación que materializa la intencionalidad o finalidad del delito inicial. Es precisamente el riesgo de explotación sexual lo que determina la elevada penalidad prevista en este tipo delictivo, máxime cuando se trata de menores, en cuyo caso la finalidad califica por sí misma la acción delictiva como trata de seres humanos, sin necesidad de haber utilizado los medios coactivos previstos en el párrafo primero del precepto En consecuencia, en estos casos la explotación sexual constituye, en cierto modo, un agotamiento de la conducta de trata, por lo que nos encontramos ante un delito instrumento y un delito fin, lo que hace procedente aplicar, en beneficio de los recurrentes aunque no lo hayan solicitado expresamente, la regla prevenida en el artículo 77 para el 


\section{Polít. crim. Vol. 11, № 22 (Diciembre 2016), Art. 6, pp. 521-547. \\ [http://www.politicacriminal.cl/Vol_11/n_22/Vol11N22A6.pdf]}

En cambio, la solución sería distinta si la norma que entra en conflicto con el delito de trata de seres humanos también sanciona la puesta en peligro del bien jurídico protegido indirectamente en el respectivo delito de trata de seres humanos. Esta situación se daría, por ejemplo, entre el delito de trata de seres humanos con fines de extracción de órganos y el delito de tráfico de órganos humanos, en su modalidad de obtención ilegal de órganos ${ }^{58}$. Entre ellos no debería existir, como afirma gran parte de la doctrina ${ }^{59}$, un concurso de delitos, ya que se trata de un mismo hecho (facilitar la obtención ilegal de órganos) prohibido en dos tipos penales que pondrían en peligro el mismo bien jurídico (la salud pública $)^{60}$. Por ello, en este caso, parece que estamos ante un concurso de normas, a resolver por el principio de especialidad, entre el delito de trata de seres humanos con fines de extracción de órganos y el delito de tráfico de órganos, pues el primero contendría todos los elementos del segundo, en su modalidad de actos tendentes a la obtención ilegal de órganos humanos, y, a su vez, otros que lo especifican (la lesión a la integridad moral de la víctima y a su libertad de autodeterminación). Así pues, cuando el órgano hubiese sido extirpado, a mi juicio, debería apreciarse un concurso (en principio, medial) de delitos entre el delito de trata de seres humanos con fines de extracción de órganos y el correspondiente delito de lesiones, por las mismas razones por las que este se apreciaría entre el delito de trata de seres humanos con fines de explotación sexual y el de prostitución coactiva, a las que me he referido anteriormente; pero, habría que apreciar un concurso de normas entre el delito de trata de seres humanos con fines de extracción de órganos y el de tráfico de órganos humanos.

denominado concurso medial. Es claro que existe una conexión típica entre ambos tipos delictivos, delito medio y delito fin, así como una conexión lógica, temporal y espacial entre ambas conductas, la de traer a España a la menor para explotarla sexualmente, y la de su explotación posterior. También es claro que el dolo de los sujetos activos ha abarcado la comisión de ambos delitos, al actuar siguiendo un plan preordenado. Y, por último, es clara la necesidad del delito medio, para poder cometer el delito fin, pues no sería posible la explotación de la prostitución de la menor en España, sin su previo traslado a nuestro país con ducha finalidad que es la conducta que integra el delito de trata de seres humanos. Concurren, por ello, en el supuesto actual, los requisitos propios del concurso medial". En cambio, la Sentencia de la AP de Madrid 261/2014, de 12 de junio, apreció un concurso ideal entre estos mismos delitos (el de trata de seres humanos con fines de explotación sexual y el de prostitución coactiva).

${ }^{58}$ Sobre la regulación jurídico-penal del delito de tráfico de órganos humanos en España y Chile, véase MOYA GUILLEM, Clara, "El tráfico de órganos humanos. Estudio de su sanción en la legislación chilena y española", Revista de Estudios de la Justicia, no 20 (2014), pp. 87-111. Sobre algunos de los principales problemas que plantea el delito de tráfico de órganos humanos en la legislación española, véase JUANATEY DORADO, Carmen, "Protección penal de la vida y de la salud: alcance del reconocimiento de la autonomía de la voluntad", en: DOVAL PAIS, A. (Dir.), Nuevos límites penales para la autonomía individual y la intimidad, Pamplona: Aranzadi, 2015, pp. 34-38.

${ }^{59}$ Entre otros, CARRASCO ANDRINO, María del Mar, El comercio de órganos humanos para trasplante, Valencia: Tirant lo Blanch, 2015, pp. 139-140; REQUEJO NAVEROS, "El delito de trata de seres humanos en el Código penal español", cit. nota $\mathrm{n}^{\circ}$ 34, p. 54; MARTOS NÚÑEZ, "El delito de trata de seres humanos: análisis del artículo 177 bis del Código penal”, cit. nota $n^{\circ} 22$, p. 110; y MUÑOZ CONDE, Derecho penal. Parte especial, cit. nota $\mathrm{n}^{\mathrm{o}}$ 34, p. 134.

${ }^{60}$ La Historia de la Ley chilena núm. 20.507 ya puso de manifiesto que "en lo relativo a la extracción de órganos a que alude la indicación, el Honorable Senador señor Chadwick indicó que ella se encuentra sancionada en otros cuerpos legales y que es objeto de atención legislativa en otro proyecto de ley, relativo a la donación de órganos, por lo que podrían presentarse problemas de colisión de cuerpos legales distintos que regulan la misma materia de incluirse tal referencia en este proyecto". 
MOYA, Clara. "Los delitos de trata de seres humanos en España y Chile. Bien jurídico protegido y relaciones concursales".

\section{Conclusiones.}

El delito de trata de seres humanos previsto en la legislación española y también el establecido en el Código penal chileno han incorporado, prácticamente en los mismos términos, las exigencias que el Derecho internacional imponía en este ámbito. Precisamente esta similitud entre las dos figuras delictivas, permite que el análisis del bien jurídico protegido en ambos tipos y la relación concursal entre estos y los delitos que materializan la explotación que con la trata de seres humanos se persigue puedan llevarse a cabo de una manera conjunta. Es más, los resultados alcanzados en el presente estudio, en principio, podrían servir para el examen de los delitos de trata de seres humanos previstos en la mayoría de los Estados latinoamericanos y europeos, pues en ellos la incriminación de la trata de seres humanos procede de los mismos instrumentos normativos internacionales y se ha incorporado a los ordenamientos jurídicos de una manera prácticamente idéntica.

Como he expuesto, los delitos de trata de seres humanos tutelarían, por un lado, la integridad moral de la víctima y su libertad de autodeterminación, que son los bienes que se lesionarían con las conductas constitutivas de trata de seres humanos; y, por otro lado, dependiendo del caso, los derechos laborales de los trabajadores, la libertad sexual de la víctima o la salud pública, que son los intereses que se pondrían en peligro en cada una de las modalidades delictivas de la trata de seres humanos. Por lo tanto, estaríamos ante delitos pluriofensivos porque los Estados examinados han decidido tipificar sólo la trata de seres humanos cuando se lleva a cabo con ciertos fines de explotación (en este caso, laboral, sexual y de extracción de órganos humanos).

El desenlace, en cambio, podría haber sido distinto si se hubiese sancionado la trata de seres humanos con fines de explotación, sin un numerus clausus de finalidades, como exigía, de manera prioritaria, el Protocolo de Palermo. En este hipotético caso, podría haberse sostenido que los delitos de trata de seres humanos tutelarían, exclusivamente, la integridad moral del sujeto pasivo y su libertad de autodeterminación. Pero, estos ilícitos, así previstos, no protegerían ni los derechos laborales de los trabajadores, ni la libertad sexual de la víctima, ni tampoco la salud pública.

Por ello, si se hubiesen previsto en estos términos los delitos de trata de seres humanos la solución en caso de concurrencia de normas penales hubiese sido absolutamente distinta. Así, mientras que, actualmente, parece existir un concurso de normas entre los delitos de trata de seres humanos y los que también sancionan la puesta en peligro del objeto amparado indirectamente en los delitos de trata de seres humanos; si no se hubiese previsto un numerus clausus de finalidades de explotación probablemente se apreciaría un concurso ideal de delitos entre ellos. Es decir, mientras que de la regulación actual se infiere, por ejemplo, que entre el delito de trata de seres humanos y el de tráfico de órganos humanos existe un concurso de normas; si la trata de seres humanos se hubiese incriminado, como pretendía el Protocolo de Palermo, con cualquier finalidad de explotación, se apreciaría un concurso ideal de delitos. Ello sería así porque ya no coincidiría el bien jurídico protegido, pues el delito de trata de seres humanos tutelaría exclusivamente la integridad moral de la víctima y su libertad de autodeterminación, y el delito de tráfico de órganos humanos protegería la salud pública. 
Polít. crim. Vol. 11, № 22 (Diciembre 2016), Art. 6, pp. 521-547.

[http://www.politicacriminal.cl/Vol_11/n_22/Vol11N22A6.pdf]

En conclusión, aunque tras una primera aproximación parece que los delitos de trata de seres humanos se hayan incorporado a las legislaciones nacionales en los términos establecidos en el Protocolo de Palermo, estas previsiones tienen un alcance distinto. Por esta razón, aunque se estima que "es en él [en el Derecho internacional] donde hay que rastrear el sentido y alcance de lo prohibido, argumento preliminar para decidir en cada Derecho nacional cuál es el bien jurídico que yace tras el delito correspondiente y quién aparece como su titular o portador" ${ }^{61}$, lo cierto es que los delitos de trata de seres humanos tienen una trayectoria mucho más limitada que la que se pretendía desde el Derecho internacional.

${ }^{61}$ GUZMÁN DALBORA, "La trata de seres humanos y el problema de su bien jurídico", cit. nota n 23, p. 14. 
MOYA, Clara. "Los delitos de trata de seres humanos en España y Chile. Bien jurídico protegido y relaciones concursales".

\section{BIBLIOGRAFÍA}

AGUILAR ARANELA, Cristian, Delitos sexuales. Tráfico ilícito de migrantes y trata de personas con fines de prostitución y explotación. Grooming, doctrina y jurisprudencia, Santiago de Chile: Ed. Metropolitana, 2012.

ALONSO ÁLAMO, Mercedes, “¿Protección penal de la dignidad? A propósito de los delitos relativos a la prostitución y a la trata de personas para la explotación sexual", Revista Penal, no 19 (2007), p. 6.

BEDMAR CARRILLO, Eulogio, "El bien jurídico protegido en el delito de trata de seres humanos", La Ley Penal, no 94-95 (2012), pp. 82-95.

BENÍTEZ ORTÚZAR, Ignacio Francisco, "Capítulo 10. Trata de seres humanos", en: MORILlAS CUEVA, Lorenzo (Coord.), Sistema de Derecho penal español. Parte especial, Madrid: Dykinson, Madrid, 2011, pp. 213-231.

BOLAÑOS VÁSQUEZ, Hazel Jasmin, "Regulación jurídico-penal de la trata de personas según el Protocolo de Palermo. Aplicación práctica desde la teoría del delito", Revista de Derecho Migratorio y Extranjería, no 34 (2013), pp. 295-314.

BOLDOVA PASAMAR, Miguel Ángel, et al, "Trata de seres humanos. En especial menores", Revista de Derecho migratorio y Extranjería, $\mathrm{n}^{\circ} 23$ (2010), pp. 51-112.

BÖSE, Martin, "Derechos fundamentales y Derecho penal como Derecho coactivo", en: HEFENDEHL, Roland (Ed.), La teoría del bien jurídico, ifundamento de legitimación del derecho penal o juego de abalorios dogmático?, Madrid: Marcial Pons, 2007, pp. 137-146.

CAMAÑO ROSA, Antonio, "Delitos contra la libertad", Anuario de Derecho penal y ciencias penales, Tomo 20 (1967), p. 57-95

CANO PAÑOS, Miguel Ángel, "De la trata de seres humanos", en: MORILLAS CUEVA, Lorenzo (Dir.), Estudios sobre el Código penal reformado, Madrid: Dykinson, 2015, pp. 421-432.

CARNEVALI, Raúl, "La trata de personas y la normativa internacional. Algunas consideraciones de su regulación en Chile", Revista de Diritto Penale Contemporaneo, $\mathrm{n}^{\circ} 4$ (2013), pp. 170-186.

CARRASCO ANDRINO, María del Mar, El comercio de órganos humanos para trasplante, Valencia: Tirant lo Blanch, 2015, pp. 139-140.

CASTELLÓ NICÁS, Nuria, El concurso de normas penales, Granada: Comares, 2000, pp. 49 y ss.

COBOS GÓMEZ DE LINARES, Miguel Angel, "Trata de seres humanos: art. 177 bis C.p.”, en: ÁLVAREZ GARCÍA, Francisco Javier (Dir.), Estudio crítico sobre el Anteproyecto de Reforma penal de 2012, Valencia: Tirant lo Blanch, 2013, p. 622

CUGAT MAURI, Miriam, "Trata de seres humanos: la universalización del tráfico de personas y su disociación de las conductas infractoras de la política migratoria”, en: QUINTERO OLIVARES, Gonzalo (Dir.), La reforma penal de 2010: Análisis y comentarios, Pamplona: Aranzadi, 2010, pp. 157-164.

DAUNIS RODRÍGUEZ, Alberto, El delito de trata de seres humanos, Valencia: Tirant lo Blanch, 2013.

DE LA CUESTA AGUADO, Paz, Delitos de tráfico ilegal de personas, objetos y mercancías, Valencia: Tirant lo Blanch, 2013, pp. 16-17. 
Polít. crim. Vol. 11, No 22 (Diciembre 2016), Art. 6, pp. 521-547.

[http://www.politicacriminal.cl/Vol_11/n_22/Vol11N22A6.pdf]

DE LA CUESTA ARZAMENDI, José Luis, “Tráfico y trata de seres humanos: regulación internacional y europea”, en: RICHARD GONZÁLEZ, Manuel, RIAÑO BRUN, Iñaki y POELEMANS, Maitena (Coords.), Estudios sobre la lucha contra la trata de seres humanos, Pamplona: Aranzadi, 2013, p. 67.

GAJARDO ORELLANA, Tania y TORRES FIGUEROA, Angélica, "Los tipos penales de tráfico de migrantes y trata de personas en la Ley 20.507”, Revista Jurídica del Ministerio Público, no 47 (2011), pp. 231-251.

GARCÍA ALBERO, Ramón, "Non bis in idem" material y concurso de leyes penales, Barcelona: Cedecs, 1995.

GARCÍA ARÁN, Mercedes, "Esclavitud y tráfico de seres humanos", en: OCTAVIO DE TOLEDO Y UBIETO, Emilio, GURDIEL SIERRA, Manuel y CORTÉS BECHIARELLI, Emilio (Coords.), Estudios penales en recuerdo del profesor Ruiz Antón, Valencia: Tirant lo Blanch, 2004, pp. 355-378.

GRACIA MARTÍN, Luis, "El delito y la falta de malos tratos en el Código penal español de 1995", Actualidad Penal, 1996, p. 581.

GUZMÁN DALBORA, José Luis, "La trata de seres humanos y el problema de su bien jurídico", Revista procesal penal, no 62 (2007), pp. 9-19.

IGLESIAS SKULJ, Agustina, "De la trata de seres humanos: artículo 177 bis C.p.", en: GONZÁLEZ CUSSAC, José Luis (Dir.), Comentarios a la reforma del Código penal de 2015, Valencia: Tirant lo Blanch, 2015, pp. 593-601.

JUANATEY DORADO, Carmen, "Protección penal de la vida y de la salud: alcance del reconocimiento de la autonomía de la voluntad", en: DOVAL PAIS, A. (Dir.), Nuevos límites penales para la autonomía individual y la intimidad, Pamplona: Aranzadi, 2015, pp. 34-38.

JUANES PECES, Ángel, "El delito de trata de seres humanos en el Proyecto de Reforma del Código penal de 1995", Actualidad Jurídica Aranzadi, no 803 (2010).

LLORIA GARCÍA, Paz, "Trata de seres humanos", en: BOIX REIG, Javier (Dir.), Derecho penal. Parte especial. Volumen I, Madrid: Iustel, 2010, pp. 293-313.

MAPELLI CAFFARENA, Borja, "La trata de personas", Anuario de Derecho penal y Ciencias penales, vol. LXV, 2012, pp. 25-62.

MARAVER GÓMEZ, Mario, "Trata de seres humanos”, en: MOLINA FERNÁNDEZ, Fernando (Coord.), Memento penal 2016, Madrid: Francis Lefebvre, 2015, pp. 944958.

MARTOS NÚÑEZ, José Antonio, "El delito de trata de seres humanos: análisis del artículo 177 bis del Código penal”, Estudios penales y criminológicos, nº 32 (2012), pp. 97130.

MIRA BENAVENT, Javier, "El concepto de violencia en el delito de coacciones", Cuadernos de Política Criminal, no 22 (1984), pp. 95-182.

MOYA GUILLEM, Clara, "El tráfico de órganos humanos. Estudio de su sanción en la legislación chilena y española", Revista de Estudios de la Justicia, no 20 (2014), pp. 87-111

MUÑOZ CONDE, Francisco, Derecho penal. Parte especial, Valencia: Tirant lo Blanch, 2015, p. 169

NIETO GARCÍA, Ángel Juan, "Concurso penal de la trata de seres humanos y utilización de menores como mendigos", Diario La Ley, no 7867 (2012). 
MOYA, Clara. "Los delitos de trata de seres humanos en España y Chile. Bien jurídico protegido y relaciones concursales".

OLAIZOLA NOGALES, Inés, “A vueltas con la inmigración ilegal y el nuevo delito de trata de personas", en: FERNÁNDEZ TERUELO, Javier Gustavo (Dir.), Estudios penales en homenaje al profesor Rodrigo Fabio Suárez Montes, Oviedo: Editorial Constitutio Criminalis Carolina, 2013, pp. 459-489.

PÉREZ ALONSO, Esteban Juan, Tráfico de personas e inmigración clandestina, Valencia: Tirant lo Blanch, 2008.

PÉREZ MACHÍO, Ana Isabel, El delito contra la integridad moral del artículo 173.1 del vigente Código penal. Aproximación a los elementos que lo definen, Bilbao: Universidad del País Vasco, 2005, p. 161

PERIS RIERA, Jaime Miguel y GARCÍA GONZÁLEZ, Javier, "El bien jurídico protegido en los delitos relativos a la manipulación genética: criterios de incriminación", en: BENÍTEZ ORTÚZAR, Ignacio Francisco, MORILLAS CUEVA, Lorenzo y PERIS RIERA, Jaime Miguel, Estudios jurídico-penales sobre genética y biomedicina, Madrid: Dykinson, 2005, p. 116

POMARES CINTA, Esther, "El delito de trata de seres humanos con finalidad de explotación laboral", Revista Electrónica de Ciencias Penales y Criminología, no 1315 (2011).

QUERALT JIMÉNEZ, Joan Josep, Derecho penal español. Parte especial, Valencia: Tirant lo Blanch, 2015, p. 172

REQUEJO NAVEROS, María Teresa, "El delito de trata de seres humanos en el Código penal español: Panorama general y compromisos internacionales de regulación", en: ALCÁCER GUIRAO, Rafael, MARTÍN LORENZO, María y VALLE MARISCAL DE GANTE, Margarita (Coords.), La trata de seres humanos: Persecución penal y protección de las víctimas, Madrid: Edisofer, 2015, pp. 19-56.

RODRÍGUEZ FERNÁNDEZ, Ignacio, “Trata de personas”, en: ORTIZ DE URBINA GIMENO, Íñigo (Coord.), Memento experto. Reforma penal, Madrid: Ediciones Francis Lefebvre, 2010, pp. 71-88.

RODRÍGUEZ PIZARRO, Gabriela, Ponencia en la mesa de trabajo "Migración, derechos humanos y ciudadanía", en la Conferencia Regional sobre Migración, disponible en http://www.crmsv.org/documentos/SEGIB/7\%20terceraParte.pdf [última consulta: 13/11/2015].

SANTANA VEGA, Dulce, "Artículo 177 bis del Código penal", en: CORCOY BIDASOLO, Mirentxu (Dir.), Manual de Derecho penal. Parte especial. Tomo 1, Valencia: Tirant lo Blanch, 2015, pp. 192-206.

,"El nuevo delito de trata de seres humanos", Cuadernos de Política Criminal, $\mathrm{n}^{\circ}$ 104 (2011), pp. 79-108.

SOTO DONOSO, Francisco, "Aspectos dogmáticos del delito de trata de personas del artículo $3^{\circ}$ del Protocolo de Palermo", Revista Jurídica del Ministerio público, $\mathrm{n}^{\circ} 39$ (2009), pp. 170-184.

TERRADILLOS BASOCO, Juan María, "Trata de seres humanos", en: ÁLVAREZ GARCÍA, Francisco Javier y GONZÁLEZ CUSSAC, José Luis (Dirs.), Comentarios a la reforma de 2010, Valencia: Tirant lo Blanch, 2010, pp. 207-217.

TOMÁS-VALIENTE LANUZA, Carmen, "La dignidad y sus consideraciones normativas en la argumentación jurídica: ¿un concepto útil?”, Revista Española de Derecho Constitucional, nº 102 (2014), pp. 167-208. 
Polít. crim. Vol. 11, № 22 (Diciembre 2016), Art. 6, pp. 521-547.

[http://www.politicacriminal.cl/Vol_11/n_22/Vol11N22A6.pdf]

VILLACAMPA ESTIARTE, Carolina, El delito de trata de seres humanos. Una incriminación dictada desde el Derecho internacional, Pamplona: Aranzadi, 2011. , “Título VII bis", en: QUINTERO OLIVARES, Gonzalo (Dir.), Comentarios a la Parte especial del Derecho penal, Pamplona: Aranzadi, 2011, pp. 265-303.

,"Víctimas de la trata de seres humanos: su tutela a la luz de las últimas reformas penales sustantivas y procesales proyectadas", Indret, $\mathrm{n}^{\circ} 2$ (2014).

, "La trata de seres humanos tras la reforma del Código penal de 2015", Diario La Ley, $\mathrm{n}^{\circ} 8554$ (2015). 